\title{
PERILAKU PERMINTAAN UANG DALAM SISTEM MONETER GANDA DI INDONESIA
}

\author{
Ascarya, Heni Hasanah, Noer Azam Achsani ${ }^{1}$
}

\begin{abstract}
The cotemporary dual monetary system is characterized by an interest system in conventional system and the profit-and-loss sharing (PLS) system in Islamic system, where each of them has a different behavior in influencing the money demand and the monetary stability. This study analyses the components of money demand under both the conventional and Islamic financial system in Indonesia, using a Vector Auto Regression (VAR) and Vector Error Correction Model (VECM) methods.

The results show that in Islamic system, PLS return negatively correlated with all Islamic demand for money components (currency, Wadiah demand deposit, Mudharabah saving deposit, and Mudharabah time deposit). While in conventional system, interest is negatively correlated with the demand for currency, the demand deposit, and the saving deposit, but positively correlated with the demand for time deposit. The Islamic demand for money stabilizes quiclier to respons the shock from other variables compare to conventional system. Moreover, the interest rate contributes 20\%-29\% in the conventional demand for money variation, while in PLS system the return almost has no role on Islamic money demand variation. Our research also shows that the savings deposits in Indonesia have the characteristics of the demand deposits, hence preferably included in $\mathrm{M} 1$ instead of in M2.

These findings suggest the monetary authority to gradually shift their mindset from the conventional monetary operation to the dual monetary operation and explore further the possibility of using PLS return as the "policy rate" benchmark to achieve the principal objectives in maximizing distributive social welfare and justice, as well as minimizing inefficiency.
\end{abstract}

JEL Classification: C32, E31, E41, E52

Keywords: Permintaan Uang Konvensional, Permintaan Uang Islam, Sistem Keuangan/Perbankan Ganda, VARNECM

\footnotetext{
1 Ascarya is a senior researcher in Center for Central Banking Education and Studies, Central Bank of Indonesia, Jl M. H. Thamrin 2, Sjafruddin Prawiranegara Tower, $20^{\text {th }} \mathrm{fl}$., Jakarta 10110, Indonesia (ascarya@bi.go.id); Hasanah is a researcher in International Center for Applied Finance \& Economics (Inter CAFÉ), Department of Economics, Faculty of Economics and Management, Bogor Agricultural University, Indonesia (heni_hasahah@yahoo.co.id); Achsani is a lecturer and researcher in International Center for Applied Finance \& Economics (Inter CAFÉ), Department of Economics, Faculty of Economics and Management, Bogor Agricultural University. Currently visiting researcher at Center for Central Banking Education and Studies, Bank Indonesia (achsani@yahoo.com).
} 


\section{PENDAHULUAN}

Dalam beberapa tahun terakhir, sistem keuangan internasional semakin berkembang pesat, khususnya sistem keuangan Islam. Perkembangan yang sangat pesat khususnya terjadi pada perbankan syariah. Joharris (2007) memperkirakan bahwa saat ini lebih dari 276 lembaga keuangan Islam di dunia yang tersebar di lebih dari 70 negara, dari London, New York dan Zurich ke Timur Tengah, Afrika dan Asia dengan kapitalisasi lebih dari US\$13 miliar. Semua ini termasuk bank, reksadana, KPR dan takaful (asuransi Syariah). Jumlah dana yang dikuasai oleh Muslim lebih dari US\$13 triliun. Saat ini diperkirakan ada US\$1 triliun dana Syariah di pasar. Pasar modal Syariah global berkembang sekitar 15\% - 20\% per tahun, termasuk simpanan/investasi di bank Syariah yang diperkirakan lebih dari US\$560 miliar.

Bank Syariah di Indonesia mulai terkenal ketika terbukti di masa krisis tahun 1997-1998 Bank Muamalat Indonesia, satu-satunya bank Syariah saat itu, dapat bertahan tanpa bantuan pemerintah. Semenjak itu perbankan Syariah mulai bermunculan sebagai lembaga keuangan alternatif yang bebas dari bunga.

Operasi bank syariah yang tidak menggunakan sistem bunga dalam semua aktivitasnya digantikan utamanya dengan sistem bagi hasil, ditambah dengan sistem jual beli dan sewa. Inilah perbedaan utama sistem keuangan Islam pada masa kontemporer ini dengan sistem keuangan konvensional. Secara konseptual sistem keuangan Islam yang ideal tidak menggunakan uang fiat dan juga tidak menggunakan fractional reserve banking system sebagaimana dianut oleh sistem keuangan konvensional, karena keduanya mengandung unsur riba di dalamnya. Meskipun system keuangan Islam tumbuh pesat di seluruh dunia, termasuk Indonesia, porsinya masih sangat kecil (di Indonesia kurang dari 2\%) sehingga, meskipun banyak negara telah menerapkan sistem keuangan ganda, secara keseluruhan sistem keuangan Islam masih terdominasi oleh kekuatan sistem keuangan konvensional yang berbasis bunga, uang fiat, dan fractional reserve banking system.

Secara teoritis, para ahli ekonomi Islam, yang memberi perhatian terhadap perkembangan sistem keuangan Islam, menunjukan bahwa konsep bagi hasil jauh lebih baik daripada instrumen suku bunga yang digunakan oleh sistem keuangan konvensional dilihat dari segi keadilan, reduksi kegiatan spekulasi, efisiensi sumber daya, dan lain-lain (Lihat misalnya: Khan, 1986 sampai Zangeneh, 1995; Fardmanesh dan Siddiqui, 1995; Meera, 2004; Ryandono, 2006; Ascarya, 2007; dan Sakti, 2007). Oleh karena itu, harus dibuktikan secara empiris bahwa dengan tidak adanya instrumen suku bunga dalam sistem keuangan Islam yang digantikan dengan konsep bagi hasil ini dapat mendukung sistem 
keuangan ganda secara keseluruhan, khususnya dalam studi permintaan uang dan stabilitas moneter dalam sistem keuangan/perbankan ganda.

Tujuan dari penelitian ini, pertama, adalah untuk merumuskan fungsi permintaan uang yang didefinisikan secara konvensional dan permintaan uang yang sesuai dengan ajaran Islam. Kedua, penelitian ini akan menganalisis tentang bagaimana dampak dari adanya pelarangan sistem bunga yang digantikan oleh sistem bagi hasil dalam sistem keuangan Islam terhadap stabilitas agregat moneter.

\section{TEORI}

\section{II.1 Sistem Moneter Konvensional dan Sistem Moneter Islam}

Secara garis besar ada tiga pilar sistem moneter yang membedakan satu dengan lainnya, yaitu sistem uang, sistem perbankan, dan sistem operasi keuangannya. Perbedaan utama sistem moneter Islam secara konseptual, sistem moneter Islam kontemporer dan sistem moneter konvensional ditunjukkan dalam tabel IV.1 berikut (Ascarya, 2007).

\begin{tabular}{|c|c|c|c|}
\hline \multicolumn{4}{|c|}{$\begin{array}{l}\text { Tabel IV.1. } \\
\text { Perbandingan Sistem Moneter Konvensional dan Sistem Moneter Islam }\end{array}$} \\
\hline No. & Konvensional & Islam Konseptual & Islam Kontemporer \\
\hline 1. & Sistem Uang Fiat & $\begin{array}{l}\text { Sistem Uang Islam - full bodied/ } \\
\text { fully backed money }\end{array}$ & Sistem Uang Fiat \\
\hline 2. & Fractional Reserve Banking System & 100 Percent Reserve Banking System & Fractional Reserve Banking \\
\hline 3. & Sistem Bunga & Sistem Bagi Hasil & Sistem Bagi Hasil \\
\hline
\end{tabular}

Dalam sistem keuangan ganda yang ada saat ini, hanya konsep bagi hasil saja yang menjadi pembeda antara sistem moneter konvensional dan sistem moneter Islam. Sistem moneter Islam dalam sistem keuangan ganda masih menggunakan uang fiat konvensional dan masih menerapkan fractional reserve banking system (baca table IV.1, kolom kanan). Karakteristik sistem bunga sendiri sangat berbeda dengan karakteristik sistem bagi hasil. Suku bunga sebagai tingkat pengembalian pada sistem konvensional bisa ditetapkan kapan saja oleh otoritas perbankan dan pergerakan nominalnya bisa terlihat oleh masyarakat umum, sehingga menimbulkan kegiatan spekulasi. Sedangkan dalam sistem bagi hasil yang ditetapkan adalah nisbahnya yang nilainya tetap sepanjang akad berlaku. Sedangkan tingkat pengembaliannya 
mengikuti hasil yang benar-benar terjadi di lapangan. Artinya, return itu sendiri tidak ditetapkan secara eksogenus oleh otoritas perbankan Syariah.

\section{II.2 Perbandingan Sistem Bunga dan Sistem Bagi Hasil}

Sebagai alternatif sistem bunga dalam ekonomi konvensional, ekonomi Islam menawarkan sistem bagi hasil (profit-and-loss sharing/PLS), ketika pemilik modal (surplus spending unit) bekerja sama dengan pengusaha (deficit spending unit) untuk melakukan kegiatan usaha. Apabila menghasilkan keuntungan dibagi berdua, apabila menderita kerugian juga ditanggung bersama. Sistem bagi hasil menjamin adanya keadilan dan tidak ada pihak yang tereksploitasi (didzalimi). Sistem bagi hasil dapat berbentuk Musyarakah atau Mudharabah dengan berbagai variasinya.

Bank konvensional, return-nya dari sistem bunga yaitu persentase terhadap dana yang disimpan ataupun dipinjamkan dan ditetapkan diawal transaksi sehingga berapa nilai nominal rupiahnya akan dapat diketahui besarnya dan kapan akan diperoleh dapat dipastikan tanpa melihat laba rugi yang akan terjadi nanti. Sedang bank Syariah, return-nya dari sistem bagi hasil (PLS) yaitu nisbah (persentase bagi hasil) yang besarnya ditetapkan diawal transaksi yang bersifat fixed tetapi nilai nominal rupiahnya belum dapat diketahui dengan pasti melainkan melihat laba rugi yang akan terjadi nanti.

Pada Gambar IV.1 dapat terlihat bahwa dalam perekonomian konvensional, sistem riba, fiat money, fractional reserve system dalam perbankan, dan diperbolehkannya spekulasi

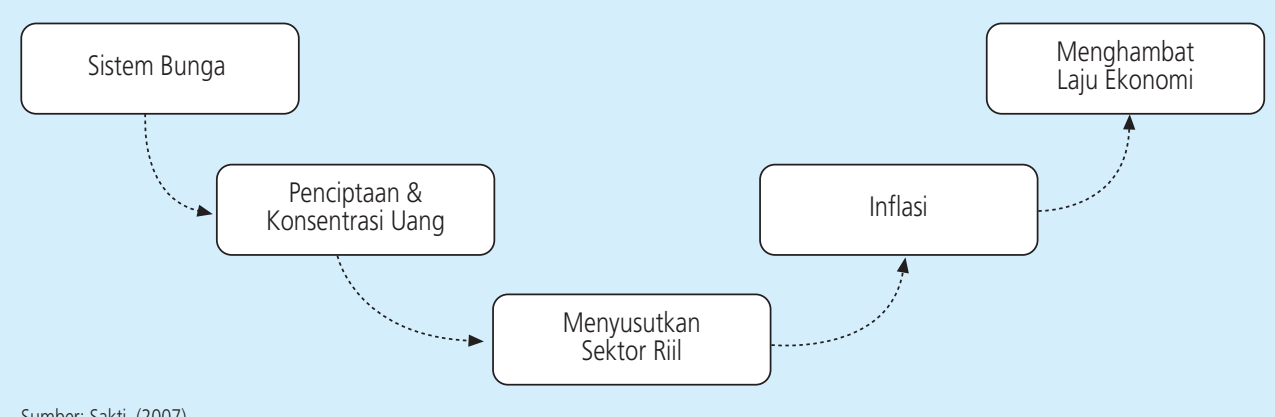

Sumber: Sakti (2007)

Gambar IV.1.

Implikasi Bunga pada Perekonomian 
menyebabkan penciptaan uang (kartal dan giral) dan tersedotnya uang di sektor moneter untuk mencari keuntungan tanpa risiko. Akibatnya, uang atau investasi yang seharusnya tersalur ke sektor riil untuk tujuan produktif sebagian besar lari ke sektor moneter dan menghambat pertumbuhan bahkan menyusutkan sektor riil. Penciptaan uang tanpa adanya nilai tambah akan menimbulkan inflasi. Pada akhirnya, tujuan pertumbuhan ekonomi akan terhambat.

Sementara itu, pada Gambar IV.2 dengan sistem bagi hasil, disertai sistem zakat dan pelarangan spekulasi dalam perekonomian Islam, akan mendorong iklim investasi yang akan tersalur dengan lancar ke sektor riil untuk tujuan yang sepenuhnya produktif. Hal ini akan menjamin terdistribusinya kekayaan dan pendapatan serta menumbuhkan sektor riil. Dengan meningkatnya produktivitas dan kesempatan bekerja dan berusaha pada akhirnya pertumbuhan ekonomi terdorong, dan pada akhirnya akan tercapai kesejahteraan masyarakat.

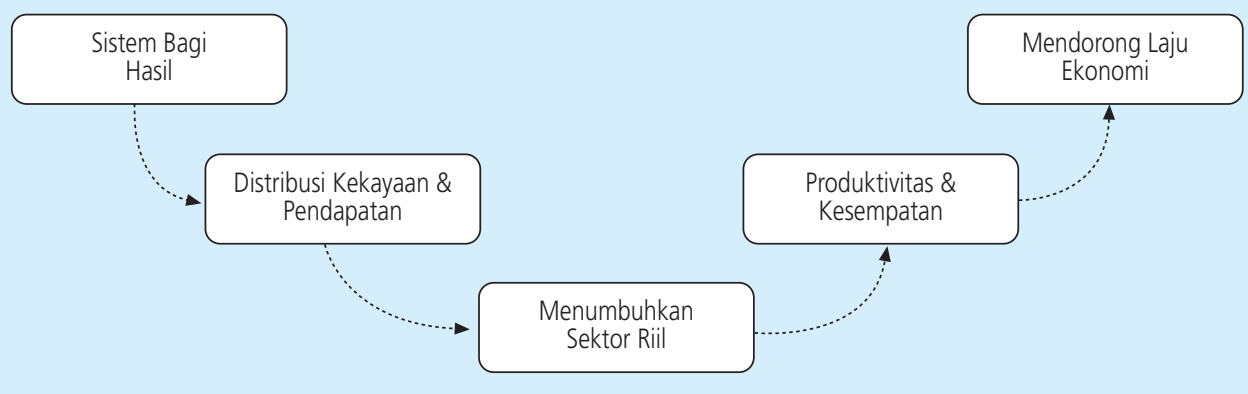

Sumber: Sakti (2007)

Gambar IV.2.

Implikasi Bagi Hasil Pada Perekonomian

\section{II.3 Teori Permintaan Uang}

Jumlah uang beredar adalah jumlah uang yang tersedia (Mankiw, 2003). Sedangkan menurut Mishkin (2001) uang (diacu juga sebagai money supply) didefinisikan sebagai segala sesuatu yang secara umum diterima sebagai alat pembayaran barang dan jasa atau pembayaran kembali utang. Fungsi permintaan uang menurut Keynes adalah (Mishkin, 2001) :

$$
M^{d}=f(i, Y)
$$


dimana i merupakan suku bunga yang berbanding terbalik dengan permintaan uang dan $Y$ merupakan pendapatan nasional riil yang berpengaruh positif terhadap permintaan uang. Mengikuti Goldfeld dan Sichel dalam Achsani, Holtemoller, dan Sofyan (2005) permintaan terhadap keseimbangan uang riil konvensional adalah:

$$
\ln M R_{t}=\Phi_{0}+\Phi_{1} \ln Y_{t}+\Phi_{2} R_{t}+\Phi_{3} \pi_{t}
$$

dimana MR merupakan keseimbangan uang riil, Y pendapatan nasional, $\mathrm{R}$ suku bunga, dan $\pi$ ekspektasi inflasi.

Sementara itu, fungsi permintaan uang dalam Islam, salah satunya dirumuskan oleh Chapra (1996) mengikuti pendekatan Keynes. Chapra mengusulkan model permintaan uang dalam ekonomi Islam sebagai berikut.

$$
M_{d}=f\left(Y_{s}, \pi, \pi\right)
$$

dimana, $Y_{s}=$ barang dan jasa yang berhubungan dengan pemenuhan kebutuhan dan investasi produktif yang sesuai dengan nilai-nilai Islam; $\mathbf{S}=$ semua nilai moral dan social dan institusi-institusi (termasuk zakat) yang mempengaruhi alokasi dan distribusi sumber daya dan dapat membantu meminimalkan $M_{d^{\prime}}$ tidak hanya yang untuk konsumsi berlebihan dan investasi tidak produktif, tetapi juga yang untuk maksud berjaga-jaga dan spekulasi; dan $\pi=$ tingkat bagi hasil dalam sistem yang tidak mengizinkan penggunaan suku bunga untuk intermediasi keuangan. Model ini belum pernah digunakan untuk kajian empiris, kemungkinan karena karakterisasi $Y_{s}$ yang normatif dan tidak mencerminkan realitas yang ada, serta nilai $S$ yang rumit dan kemungkinan tidak dapat dikuantifisir dan tidak dapat dipraktekkan.

Model permintaan uang dalam sistem keuangan ganda salah satunya dipaparkan oleh Kaleem (2000) mengikuti model yang dikembangkan oleh Ahmad dan Khan (1990) yang intinya berbasis persamaan (IV.2) dengan menghilangkan komponen suku bunga $R$, sehingga permintaan uang konvensional dan permintaan uang Islam dalam sistem keuangan ganda dapat dibandingkan, sebagai berikut.

$$
\ln M R_{t}=\Phi_{0}+\Phi_{1} \ln Y_{t}+\Phi_{2} \pi_{t}
$$

dan

$$
\ln \operatorname{MISLR}_{t}=\alpha_{0}+\alpha_{1} \ln Y_{t}+\alpha_{2} \pi_{t}
$$

Dimana MR adalah keseimbangan uang riil konvensional dan MISLR adalah keseimbangan uang riil Islam.

Model yang diajukan Kaleem (2000) mendapat kritik dari Hasanah et al (2008) karena mereka berpendapat bahwa dengan menghilangkan unsur suku bunga dari persamaan (IV.4), ciri utama sistem keuangan konvensional menjadi hilang, sedangkan return Syariah yang 
merupakan ciri sistem keuangan Islam tidak muncul dalam persamaan (5). Hasanah et al (2008) kemudian mengajukan model alternatif untuk memasukkan kembali suku bunga ke dalam persamaan permintaan uang konvensional dan memasukkan return Syariah ke dalam persamaan permintaan uang Islam sebagai variabel pembeda utama antara kedua model, yang sejalan dengan pendapat Ascarya (2007) pada tabel IV.1. Model persamaan permintaan uang dalam sistem keuangan ganda

$$
\ln M R_{t}=\Phi_{0}+\Phi_{1} \ln Y_{t}+\Phi_{2} R_{t}+\Phi_{3} \pi_{t}
$$

dan

$$
\ln \operatorname{MISLR}_{t}=\alpha_{0}+\alpha_{1} \ln Y_{t}+\alpha_{2} R S_{t}+\alpha_{3} \pi_{t}
$$

Dimana MR adalah keseimbangan uang riil konvensional, $R$ adalah suku bunga, MISLR adalah keseimbangan uang riil Islam, $R S$ adalah return Syariah, dan $\pi$ adalah ekspektasi inflasi.

\section{II.4 Penelitian Terdahulu}

Gambaran umum tentang penelitian di bidang sistem moneter Islam dalam 30 tahun terakhir dapat dibaca dalam Siddiqui (2008). Siddiqui secara kritis mengevaluasi beberapa model teoritis penting yang dikembangkan di bidang ini untuk menjelaskan berbagai hal yang masih dipertanyakan. Perlu dicatat bahwa meskipun sejumlah pertanyaan yang berhubungan dengan system moneter Islam yang relatif baru ini belum juga terjawab, ketertarikan penelitian dalam bidang ini menurun sejalan dengan kegagalan perbankan Syariah untuk menerapkan konsep bagi hasil dalam skala yang dapat mensyaratkan perubahan yang berarti dalam pelaksanaan kebijakan moneter dan instrumennya. Sejalan dengan itu, kajian yang khusus membahas tentang kerangka, manajemen, dan operasi kebijakan moneter dalam sistem keuangan/perbankan ganda masih sangat sedikit dilakukan, meskipun semakin banyak negara yang menerapkan sistem keuangan/perbankan ganda. Beberapa studi tersebut antara Iain Kaleem (2000), Darrat (2000), Kia (2001), Astiyah et al. (2006), Ascarya (2007), Izhar dan Asutay (2007), dan Hasanah et al (2008).

Kaleem (2000) melakukan penelitian tentang stabilitas moneter pada sistem perbankan ganda di Malaysia. Kaleem mengestimasi permintaan uang konvensional dan Islam tetapi menghilangkan variabel suku bunga dalam permintaan uang konvensional dan tidak menambahkan variabel return Syariah dalam permintaan uang Islam. Hasilnya menunjukkan bahwa permintaan uang konvensional sama saja dengan permintaan uang Islam yaitu tidak tahan terhadap guncangan. Penelitiannya juga menunjukkan bahwa agregat moneter M1 dan M2 baik konvensional maupun Islam berhubungan dengan tingkat harga. 
Darrat (2000) melakukan penelitian di Iran dan Pakistan dengan menggunakan data dari tahun 1960-1998. Penelitian ini dimaksudkan untuk melihat stabilitas dari permintaan uang baik pada sistem bunga maupun pada sistem non bunga dalam jangka panjang. Penelitian ini dimaksudkan juga untuk melihat stabilitas permintaan uang dari perilaku agen ekonomi baik pada sistem bunga maupun sistem bagi hasil. Hasilnya menunjukkan bahwa interest free mempunyai hubungan yang kuat dengan instrumen kebijakan dan stabilitas harga.

Sementara itu, Kia (2001) melakukan penelitian serupa di Iran dengan kurun waktu 19661998. Hasilnya menunjukkan baik pada jangka pendek maupun jangka panjang, permintaan uang pada interest-free (M1) stabil dan invarian terhadap kebijakan dan guncangan lain dalam perubahan rezim, sedangkan permintaan uang pada interest-bearing (M2) tidak stabil. Studi ini juga menunjukkan bahwa perilaku agen ekonomi terhadap asset yang berbasiskan bunga adalah cenderung forward looking sehingga ekspektasi yang terbetuk adalah rasional terhadap pasar keuangan Iran. Atau dengan kata lain bahwa koefisien permintaah uang dengan menggunakan bunga tidak terpengaruh oleh perubahan kebijakan.

Kajian sistem moneter dalam sistem perbankan ganda di Indonesia pertama kali dilakukan oleh Astiyah et al. (2006). Mereka melakukan kajian konseptual yang selanjutnya dirumuskan guna mendapatkan pendekatan yang paling cocok untuk menggambarkan perilaku sistem moneter dalam sistem perbankan ganda. Studi ini berkesimpulan bahwa dengan tidak diperkenankannya penggunaan suku bunga dalam ekonomi Islam, maka implementasi kebijakan moneter yang diambil sebaiknya cenderung kepada quantity targeting yang utuh dengan mengedepankan konsistensi antara instrumen syariah dan instrumen konvensional serta memperhatikan prinsip equality terhadap kedua jenis perbankan, baik konvensional maupun syariah.

Setelah itu, Ascarya (2007) melakukan studi deskriptif analitis tentang kebijakan moneter optimum pada sistem perbankan ganda. Hasilnya menunjukkan bahwa kebijakan moneter optimum pada suatu negara yang mengadopsi sistem perbankan atau keuangan ganda harusnya mengacu pada tingkat pengembalian pada sistem bagi hasil untuk memaksimalkan keadilan distributif dan kesejahteraan sosial dan meminimalkan inefisiensi.

Selanjutnya, Izhar dan Asutay (2007) juga melakukan penelitian tentang stabilitas moneter pada sistem perbankan ganda di Indonesia, dengan data time series dari tahun 2001 sampai 2004. Hasilnya menunjukkan bahwa baik dalam persamaan jangka panjang maupun persamaan error correction model variabel M2 konvensional dan M2 Islam tidak mempunyai hubungan yang signifikan dengan tingkat harga. Namun demikian, nilai error correction term (ECT) pada sistem konvensional lebih besar daripada ECT pada sistem Islam. 
Penelitian terbaru yang cukup penting adalah yang dilakukan oleh Hasanah et al (2008) yang mengkaji perilaku agregat moneter dalam sistem keuangan/perbankan ganda di Indonesia dari tahun 2001 sampai tahun 2006 dengan memasukkan variabel return bagi hasil dalam model permintaan uang Islam yang dikembangkan Kaleem (2000) untuk membedakan dengan model permintaan uang konvensional yang mempunyai variabel suku bunga, dengan hasil sebagai berikut.

\section{a. Perbandingan Permintaan M1 Konvensional dan Permintaan M1 Islam}

Gambar IV.3 menunjukkan bahwa guncangan suku bunga (IDEP) memberikan pengaruh negatif dan permanen terhadap M1 konvensional (LM1R), dan menjadi stabil setelah periode ke 20. Sedangkan, guncangan return Syariah (RS) memberikan pengaruh negatif dan permanen terhadap M1 Islam (LM1ISLR), dan menjadi stabil setelah periode ke 15. M1 konvensional mencapai kestabilan kembali lebih lama dengan magnitude awal lebih besar dan pengaruh permanen lebih besar.
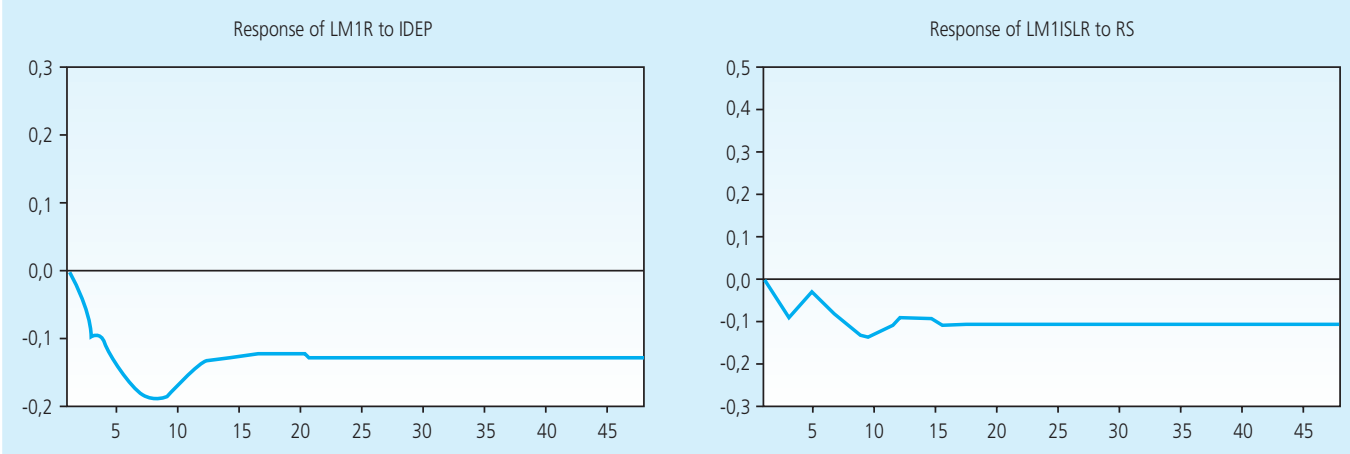

\section{Gambar IV.3.}

Respon Permintaan M1 Konvensional terhadap

Suku Bunga vs. Respon M1 Islam terhadap Return Syariah

Sementara itu, gambar IV.4 menunjukkan bahwa suku bunga (IDEP) memberikan andil cukup besar ( $\pm 20 \%$ ) dalam perilaku permintaan M1 konvensional. Sedangkan return Syariah (RS) memberikan andil sangat kecil (<5\%) dalam perilaku permintaan M1 Islam. Dengan demikian, permintaan M1 konvensional dipengaruhi oleh fluktuasi suku bunga, sedangkan permintaan M1 Islam tidak begitu dipengaruhi oleh fluktuasi return Syariah. 

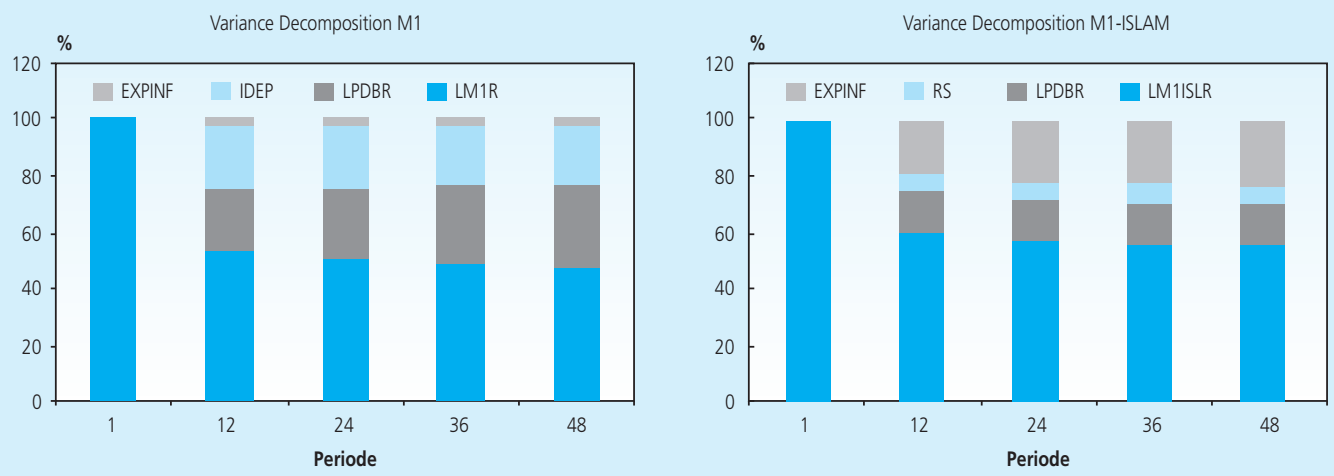

Gambar IV.4.

Variance Decomposition Permintaan M1 Konvensional vs. Permintaan M1 Islam

\section{b. Perbandingan Permintaan M2 Konvensional dan Permintaan M2 Islam}

Gambar 5 menunjukkan bahwa guncangan suku bunga (IDEP) memberikan pengaruh negatif dan permanen terhadap M2 konvensional (LM2R), dan menjadi stabil setelah periode ke 17. Sedangkan, guncangan return Syariah (RS) memberikan pengaruh negatif dan permanen terhadap M2 Islam (LM2ISLR), dan menjadi stabil setelah periode ke 15. M2 konvensional mencapai kestabilan kembali sedikit lebih lama tetapi dengan magnitude yang lebih kecil.
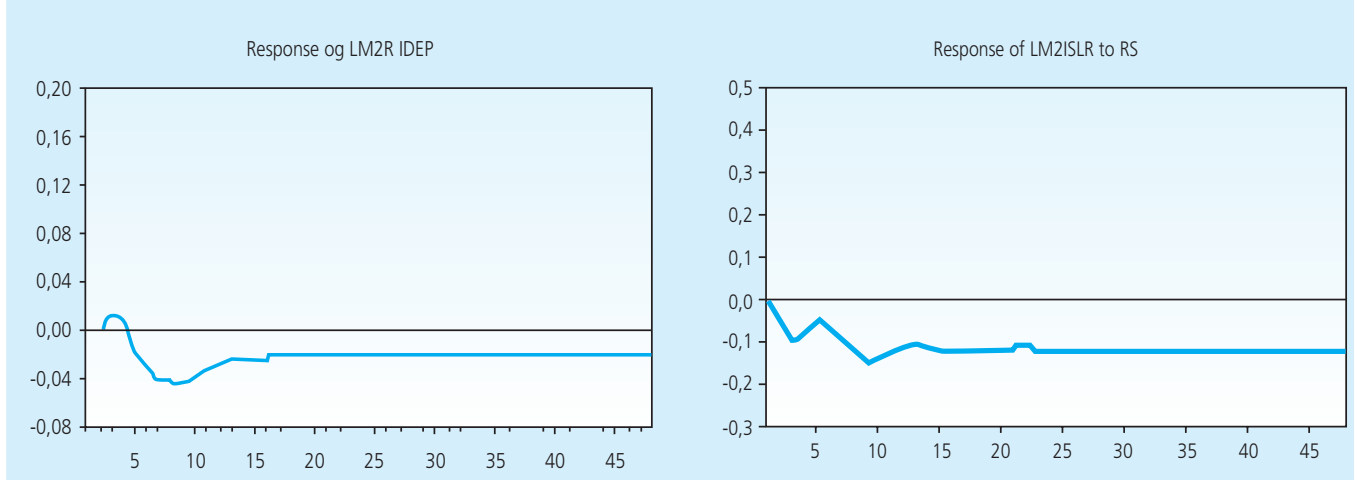

Gambar IV.5.

Respon Permintaan M2 Konvensional terhadap

Suku Bunga vs. Respon M2 Islam terhadap Return Syariah 
Gambar IV.6 menunjukkan bahwa suku bunga (IDEP) memberikan andil sangat kecil (< $5 \%$ ) dalam perilaku permintaan M2 konvensional. Sedangkan return Syariah (RS) juga memberikan andil sangat kecil (<5\%) dalam perilaku permintaan M2 Islam.
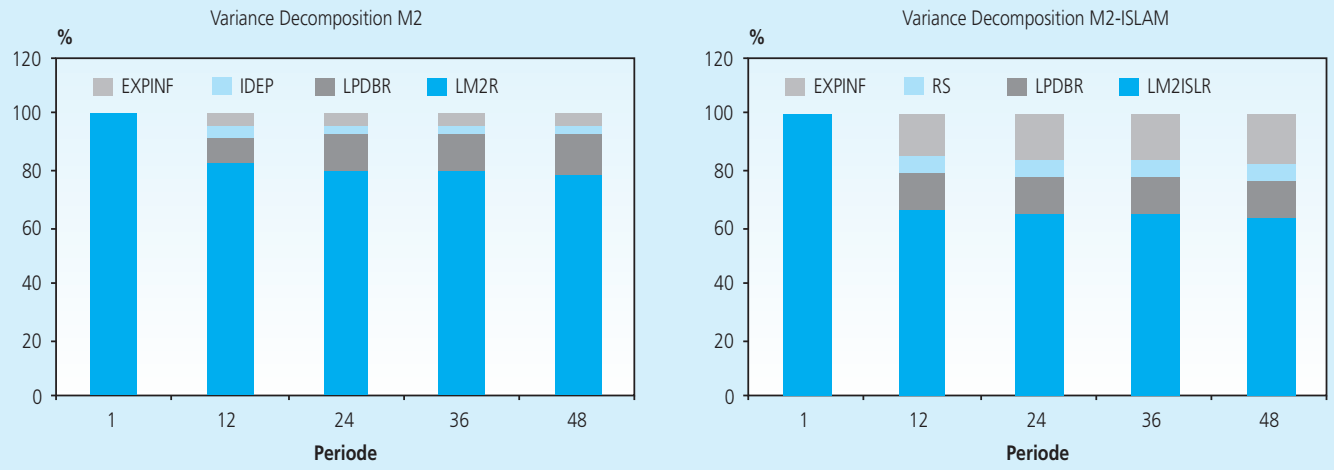

Gambar IV.6.

Variance Decomposition Permintaan M2 Konvensional vs. Permintaan M2 Islam

Adanya pergeseran perilaku M1 konvensional ke M2 konvensional menyiratkan kemungkinan adanya pengaruh positif dari suku bunga terhadap tabungan atau deposito. Besar kemungkinan suku bunga berpengaruh positif terhadap deposito konvensional karena tingginya suku bunga akan menarik masyarakat untuk menyimpan dananya di deposito. Hal ini perlu pembuktian lebih lanjut dalam penelitian berikutnya.

\section{II.5 Kerangka Konseptual}

Untuk melihat lebih jauh perbedaan perilaku permintaan uang konvensional dan permintaan uang Islam, penelitian ini dilakukan dengan mem-breakdown perilaku masing-masing komponen M1 dan M2 agar terlihat lebih jelas perbedaan perilaku mereka, dengan menggunakan model yang sama seperti persamaan (IV.6) dan (IV.7), yang secara konseptual dapat dibaca pada gambar IV.7. Variabel makroekonomi (PDB dan ekspektasi inflasi mempengaruhi permintaan (komponen) uang konvensional dan permintaan uang Islam. Sebagai opportunity cost dalam memegang uang, suku bunga mempengaruhi permintaan uang konvensional, sedangkan return Syariah mempengaruhi permintaan uang Islam. Kesemuanya itu akan mempengaruhi perilaku permintaan uang dan kestabilan moneter dalam sistem keuangan ganda. 


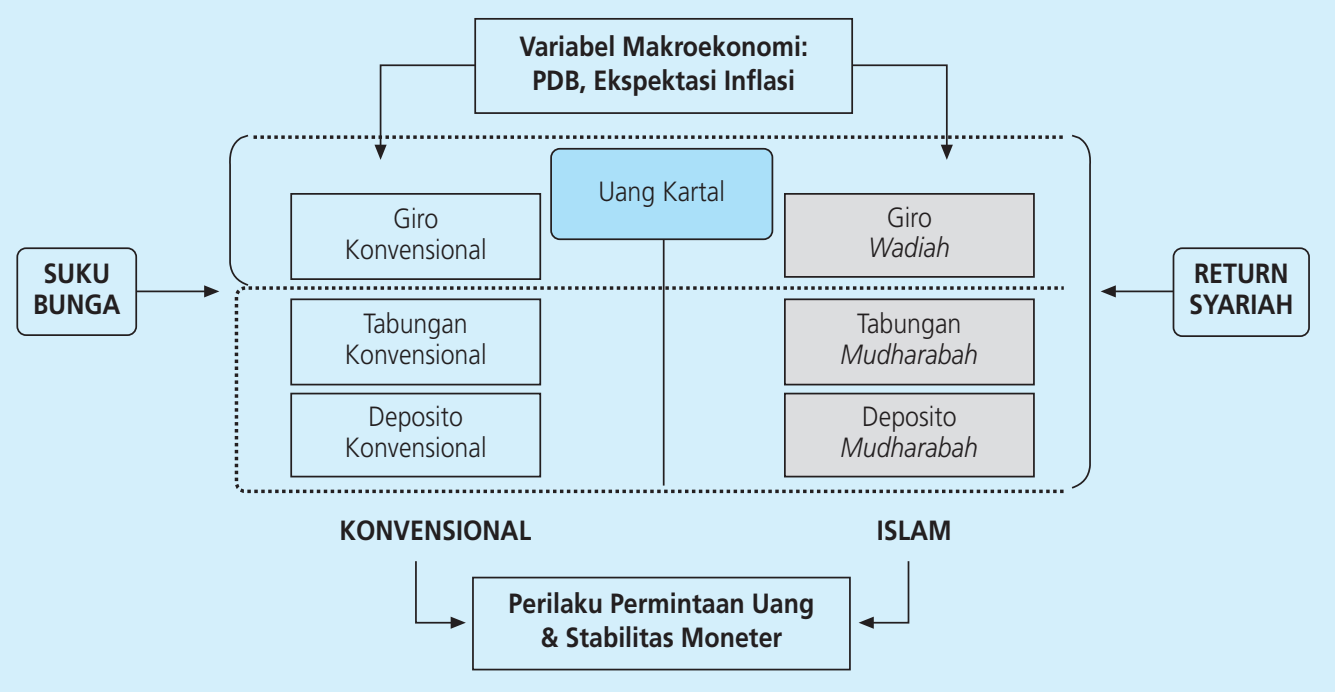

Gambar IV.7.

Komponen Agregat Moneter yang MempengaruhiPerilaku Permintaan Uang dan Stabilitas Moneter dalam Sistem Keuangan Ganda

\section{METODOLOGI}

\section{III.1 Jenis dan Sumber Data}

Data yang digunakan dalam penelitian ini seluruhnya merupakan data sekunder negara Indonesia dalam bentuk bulanan yang diperoleh dari Statistik Ekonomi dan Keuangan Indonesia Bank Indonesia (SEKI-BI) dan Statistik Perbankan Syariah Bank Indonesia (SPS-BI) serta data return Syariah dari Bank Muamalat Indonesia dalam periode waktu antara bulan Januari 2001 sampai dengan bulan Desember 2006. Dengan demikian data yang digunakan merupakan data time series.

\section{III.2 Variabel dan Definisi Operasional}

Variabel yang digunakan dalam penelitian beserta definisi operasionalnya adalah sebagai berikut.

a. Komponen uang beredar konvensional dalam arti sempit (M1) adalah uang kartal dan giro pada bank konvensional.

b. Komponen uang beredar konvensional dalam arti luas (M2) adalah komponen M1, tabungan, dan deposito pada bank konvensional. 
C. Komponen uang beredar Islam dalam arti sempit (M1ISL) adalah uang kartal dan giro Wadiah pada bank Syariah.

d. Komponen uang beredar Islam dalam arti luas (M2ISL) adalah komponen M1ISL, tabungan Mudharabah, dan deposito/investasi Mudharabah.

e. Tingkat output riil (PDB riil) adalah nilai Produk Domestik Bruto yang dideflasi dengan tingkat IHK tahun dasar 2002.

f. Ekspektasi inflasi (EXPINF) adalah tingkat inflasi pada satu periode sebelumnya dengan IHK tahun dasar 2002.

g. Suku bunga deposito (IDEP) adalah suku bunga deposito jangka waktu 6 bulan.

h. Return Syariah (RS) adalah tingkat pengembalian dana pada bank umum Syariah berupa equivalent rate dari return deposito/investasi Mudharabah.

Keterbatasan model yang digunakan adalah penggunaan uang kartal yang tidak dapat dipisahkan mana bagian uang kartal konvensional dan mana bagian uang kartal Islam, sehingga dalam analisis permintaan uang Islam M1 dan M2 di Indonesia, yang porsi perbankan Syariah masih kurang dari 2\%, akan didominasi oleh perilaku uang kartal. Hal ini mendorong penulis untuk menganalisis komponen M1 dan M2 agar dapat memisahkan pengaruh komponen uang kartal dari komponen lainnya.

\section{III.3 Metoda Estimasi}

Permasalahan pada penelitian ini akan dianalisis dengan menggunakan Vector Autoregression (VAR) dari model permintaan uang konvensional dan permintaan uang Islam yang diajukan oleh Hasanah et al (2008), seperti pada persamaan (6) dan (7). Kemudian jika data yang digunakan stasioner pada perbedaan pertama maka model VAR akan dikombinasikan dengan model koreksi kesalahan menjadi Vector Error Correction Model(VECM). Analisis impulse response function juga dilakukan untuk melihat respon suatu variabel endogen terhadap guncangan variabel lain dalam model. Analisis variance decomposititon juga dilakukan untuk melihat kontribusi relatif suatu variabel dalam menjelaskan variabilitas variabel endogenusnya. Semua data dalam penelitian ini ditransformasikan ke dalam bentuk logaritma natural (In) kecuali suku bunga, rate of return, dan inflasi yang diharapkan untuk mendapatkan hasil analisis yang lebih valid dan konsisten. Perangkat lunak yang digunakan dalam penelitian ini adalah Microsoft Excel 2003 dan program Eviews 4.1. 


\section{HASIL DAN ANALISIS}

\section{IV.1 Uji Stasioneritas Data}

Metoda pengujian yang digunakan untuk melakukan uji stasioneritas data dalam penelitian ini adalah uji ADF (Augmented Dickey Fuller) dengan menggunakan taraf nyata lima persen. Jika nilai t-ADF lebih kecil dari nilai kritis MacKinnon, maka dapat disimpulkan bahwa data yang digunakan adalah stasioner (tidak mengandung akar unit). Pengujian akar-akar unit ini dilakukan pada tingkat level sampai dengan first difference. Variabel-variabel yang digunakan dalam penelitian ini ada yang stasioner dan ada pula yang tidak stasioner pada tingkat level. Setelah dilakukan first difference barulah semua data stasioner pada taraf nyata lima persen. Hasil pengujian akar unit dapat dilihat pada tabel IV.1 dalam Lampiran.

\section{IV.2 Penetapan Lag Optimal}

Pengujian panjang lag optimal ini sangat berguna untuk menghilangkan masalah autokorelasi dalam sistem VAR. Sehingga dengan digunakannya lag optimal diharapkan tidak muncul lagi masalah autokorelasi. Penentuan lag optimal yang digunakan dalam penelitian ini berdasarkan lag terpendek dengan menggunakan Schwarz Information Criterion (SIC). Hasil pengujian penentuan lag optimal ini dapat dilihat pada tabel IV.2 dan tabel IV.3 dalam Lampiran.

\section{IV.3 Pengujian Kointegrasi}

Pengujian ini dilakukan dalam rangka memperoleh hubungan jangka panjang antar variabel yang telah memenuhi persyaratan selama proses integrasi yaitu dimana semua variabel telah stasioner pada derajat yang sama yaitu derajat 1 I(1). Informasi jangka panjang diperoleh dengan menentukan terlebih dahulu rank kointegrasi untuk mengetahui berapa sistem persamaan yang dapat menerangkan dari keseluruhan sistem yang ada. Hasil pengujian kointegrasi berdasarkan trace statistics dapat dilihat pada tabel IV.4 dan tabel IV.5 dalam Lampiran. Berdasarkan lampiran tersebut menunjukkan bahwa untuk masing-masing persamaan terdapat minimal satu rank kointegrasi pada taraf nyata lima persen.

\section{IV.4 Permintaan Uang Kartal}

\section{a. Analisis Impulse Response Function untuk Uang Kartal}

Rangkuman hasil analisis IRF untuk permintaan uang kartal (konvensional dan Islam) dapat dibaca pada tabel IV.7, serta gambar IV.8 dan gambar IV.9 di Lampiran. 


\begin{tabular}{|c|c|c|}
\hline \multicolumn{3}{|c|}{$\begin{array}{c}\text { Tabel IV.7. } \\
\text { Respon Permintaan Uang Kartal }\end{array}$} \\
\hline & $\begin{array}{c}\text { Respon Permintaan } \\
\text { Uang Kartal Konvensional }\end{array}$ & $\begin{array}{c}\text { Respon Permintaan } \\
\text { Uang Kartal Islam }\end{array}$ \\
\hline & $\begin{array}{l}\text { Positif dan permanen } 0.015 \text {, } \\
\text { stabil mulai periode ke- } 40\end{array}$ & $\begin{array}{l}\text { Positif dan permanen } 0.015 \text {, } \\
\text { stabil mulai periode ke- } 25\end{array}$ \\
\hline Guncangan Ekspektasi Inflasi & $\begin{array}{l}\text { Negatif dan permanen }-0.01 \text {, } \\
\text { stabil mulai periode ke-34 }\end{array}$ & $\begin{array}{l}\text { Negatif dan permanen }-0.02 \text {, } \\
\text { stabil mulai periode ke- } 20\end{array}$ \\
\hline Guncangan Suku Bunga & $\begin{array}{l}\text { Negatif dan permanen }-0.02 \text {, } \\
\text { stabil mulai periode ke- } 26\end{array}$ & - \\
\hline Guncangan Return Mudharabah & - & $\begin{array}{l}\text { Negatif dan permanen }-0.01 \text {, } \\
\text { stabil mulai periode ke- } 18\end{array}$ \\
\hline
\end{tabular}

Gambar IV.8 di Lampiran menunjukkan bahwa respon permintaan uang kartal terhadap guncangan variabel lainnya berfluktuasi. Permintaan uang kartal merespon positif berkisar 1.1 sampai 2.8 persen dari mulai periode kelima sampai periode ke-48 terhadap guncangan variabel GDP sebesar satu standar deviasi. Sedangkan guncangan pada variabel suku bunga dan ekspektasi inflasi direspon negatif oleh permintaan uang kartal. Permintaan uang kartal dapat dikatakan stabil dalam merespon guncangan GDP setelah periode ke-37, dengan respon ratarata sebesar 1.5 persen. Permintaan uang kartal mulai stabil dalam merespon guncangan ekspektasi inflasi pada periode ke-26 dengan respon sebesar 0.9 persen. Sedangkan guncangan pada suku bunga mulai direspon stabil pada periode ke-24 sebesar 1.7 sampai 1.8 persen.

Gambar IV.9 di Lampiran menunjukkan bahwa respon permintaan uang kartal terhadap guncangan variabel GDP sebesar satu standar deviasi adalah positif berkisar 0.5 sampai 2.3 persen dari mulai periode keempat sampai periode ke-48. Sedangkan guncangan pada variabel return Mudharabah dan ekspektasi inflasi direspon negatif oleh permintaan uang kartal. Permintaan uang kartal dapat dikatakan stabil dalam merespon guncangan GDP setelah periode ke-21, dengan respon rata-rata sebesar 1.4 persen. Permintaan uang kartal mulai stabil dalam merespon guncangan ekspektasi inflasi pada periode ke-19 dengan respon sebesar 1.9 persen. Sedangkan guncangan pada return Mudharabah mulai direspon stabil pada periode ke-18 sebesar 0.9 persen. 


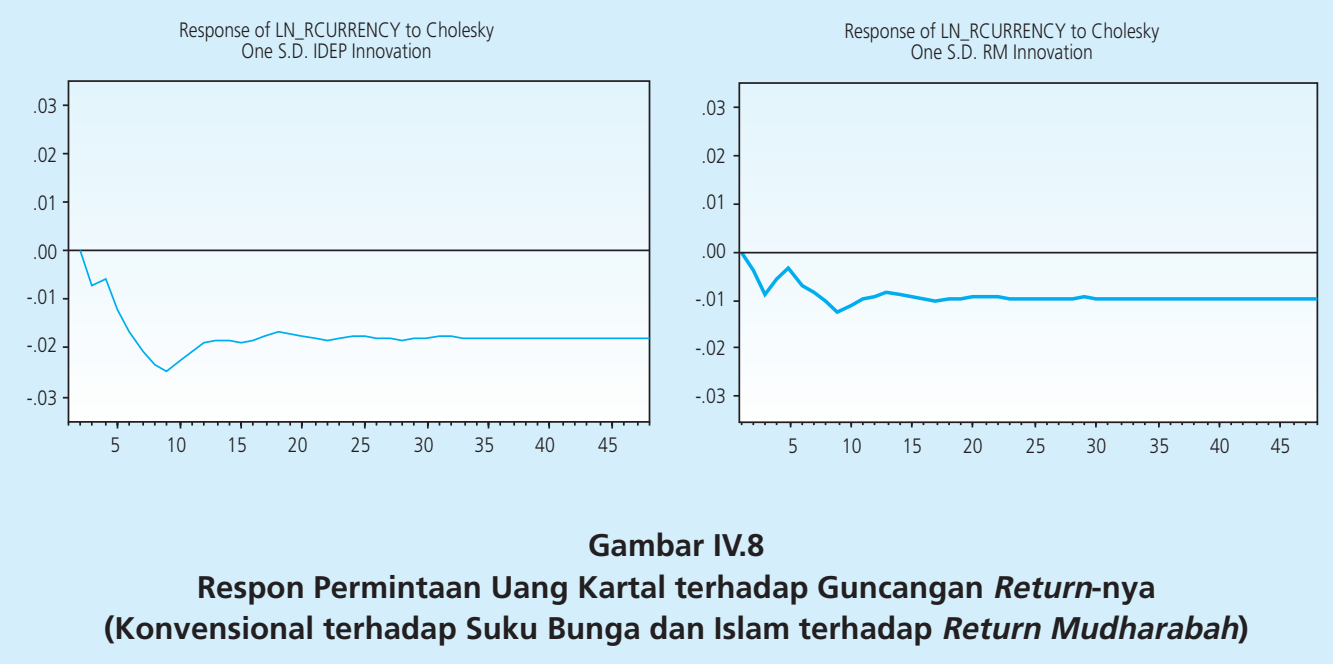

Apabila dibandingkan bersebelahan (baca gambar IV.8) terlihat bahwa, dibanding return Mudharabah, suku bunga memberikan pengaruh lebih besar (0.02 SD vs. 0.01 SD) dan lebih lama (24 periode vs. 18 periode) terhadap permintaan uang kartal.

\section{b. Analisis Variance Decomposition untuk Uang Kartal}

Permintaan Uang Kartal (Konvensional)

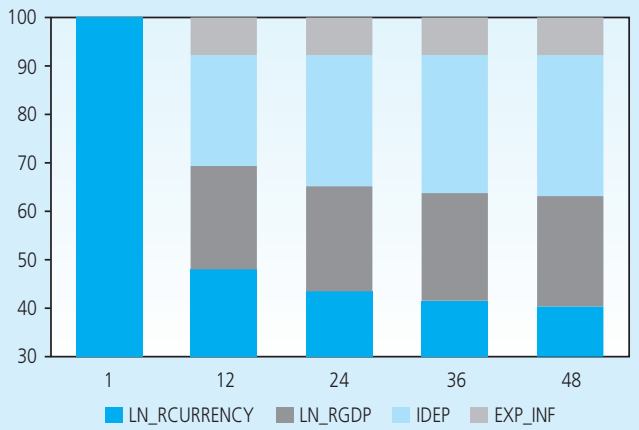

Permintaan Uang Kartal (Syariahl)

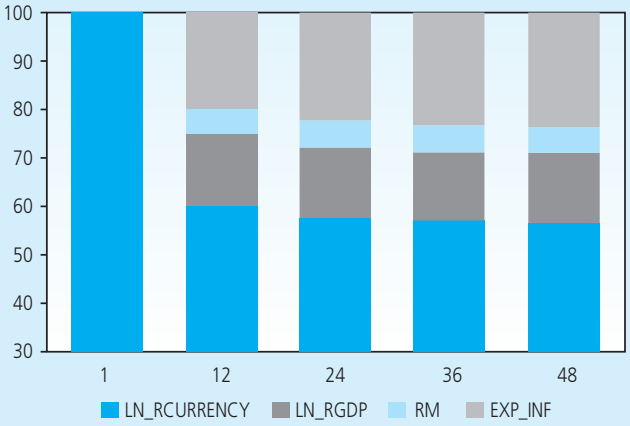

Gambar IV.9.

Variance Decomposition Permintaan Uang Kartal (Konvensional dan Islam) 
Seperti dapat dilihat pada Gambar IV.9 kiri, fluktuasi permintaan uang kartal dipengaruhi paling dominan oleh permintaan uang kartal itu sendiri, sedangkan suku bunga berada pada urutan kedua untuk periode ke-12 sampai periode ke-48, dan GDP pada urutan ketiga. Sedangkan variabel ekspektasi inflasi tidak terlalu mempengaruhi variabilitas permintaan uang kartal. Pada periode pertama, fluktuasi variabel permintaan uang kartal dipengaruhi oleh guncangan uang kartal itu sendiri sebesar 100 persen. Pada interval peramalan periode-periode selanjutnya, pengaruh guncangan permintaan uang kartal itu sendiri makin menurun mempengaruhi variabilitas permintaan uang kartal, tetapi masih dominan, sedangkan variabel suku bunga mulai berperan besar kedua. Pada periode ke-48 variabilitas uang kartal dapat dijelaskan oleh variabel suku bunga dengan kontribusi sebesar 29.2 persen.

Hasil variance decomposition permintaan uang kartal dengan memasukkan tingkat return mudharabah dapat dilihat pada Gambar IV.9 kanan. Variabilitas permintaan uang kartal dominan dipengaruhi oleh inovasi permintaan uang kartal itu sendiri, kemudian inovasi ekspektasi inflasi pada urutan kedua, dan inovasi GDP pada urutan ketiga. Sedangkan tingkat return Mudharabah justru tidak dominan dalam menjelaskan permintaan uang kartal berdasarkan hasil variance decomposition. Kontribusi rata-rata inovasi permintaan uang kartal dalam menjelaskan variabilitas permintaan uang kartal dari periode ke-12 sampai periode ke-48 adalah sebesar 61 persen.

\section{IV.5 Giro Konvensional dan Giro Wadiah}

\section{a. Analisis Impulse Response Function untuk Giro}

Rangkuman hasil analisis IRF untuk permintaan giro (konvensional dan Islam) dapat dibaca pada tabel IV.8 di bawah ini, serta gambar IV.12 dan gambar IV.13 di Lampiran.

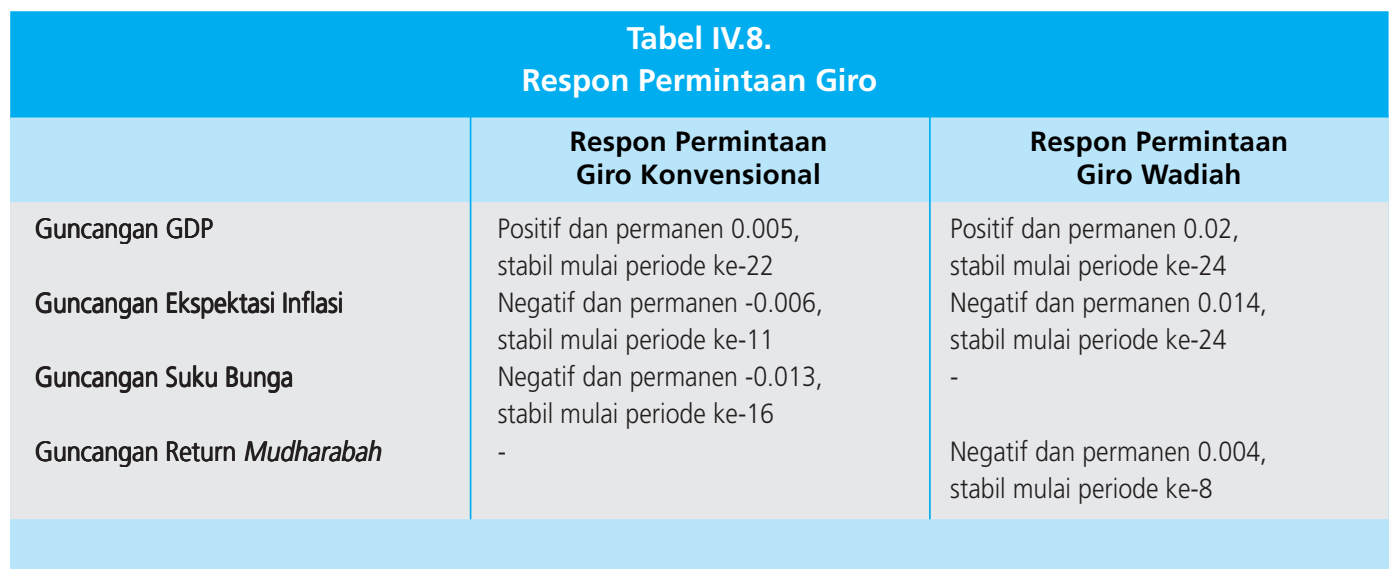


Pada Gambar IV.12 di Lampiran dapat dilihat bahwa respon giro konvensional terhadap guncangan variabel lainnya berfluktuasi. Giro konvensional merespon positif berkisar 0.1 sampai 0.9 persen dari mulai periode kedua sampai periode ke-48 terhadap guncangan variabel GDP sebesar satu standar deviasi. Sedangkan guncangan pada variabel suku bunga dan ekspektasi inflasi direspon negatif oleh giro konvensional. Giro konvensional dapat dikatakan stabil dalam merespon guncangan GDP setelah periode ke-22, dengan respon rata-rata sebesar 0.4 persen. Giro konvensional mulai stabil dalam merespon guncangan ekspektasi inflasi pada periode ketujuh dengan respon sebesar 0.5 persen. Sedangkan guncangan pada suku bunga mulai direspon stabil pada periode keenam sebesar 1.1 persen.

Gambar 13 di Lampiran menunjukkan hasil IRF permintaan giro Wadiah akibat guncangan variabel lain. Pada saat terjadi guncangan variabel GDP, giro Wadiah merespon positif dengan terjadinya kenaikan mulai dari periode kedua sampai akhir periode peramalan. Giro Wadiah dapat dikatakan stabil dalam merespon guncangan GDP setelah periode ke-26 dengan ratarata respon sebesar 1.9 persen. Guncangan variabel ekspektasi inflasi sebesar satu standar deviasi secara umum direspon negatif oleh giro Wadiah. Respon negatif ini terus berlangsung sampai akhir periode peramalan. Mulai periode ke-16, terlihat adanya kestabilan respon giro Wadiah terhadap guncangan ekspektasi inflasi sekitar 1.4 persen.
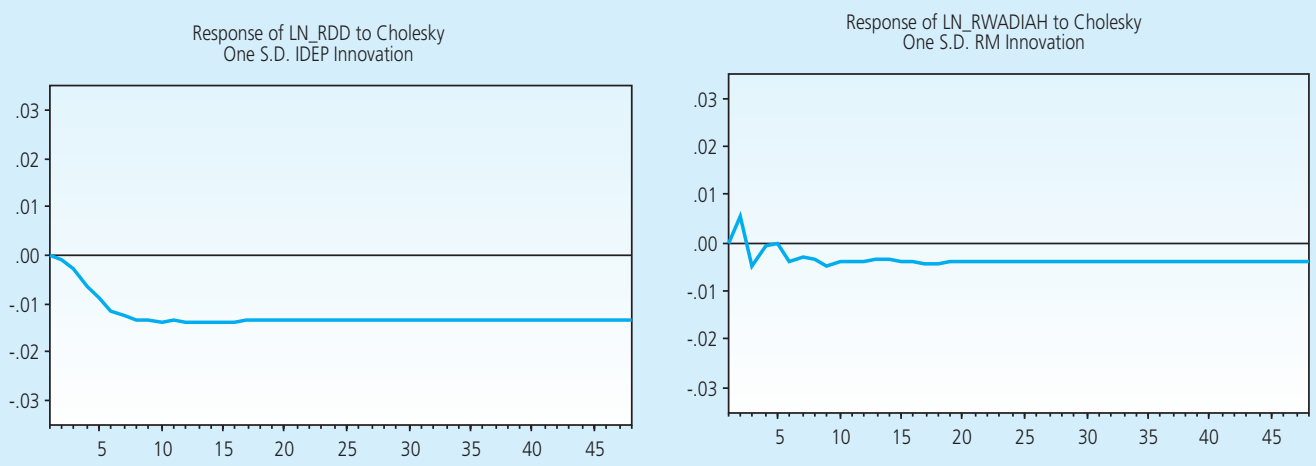

Gambar IV.10.

Respon Permintaan Giro Wadiah terhadap Guncangan Return-nya (Konvensional terhadap Suku Bunga dan Islam terhadap Return Mudharabah)

Secara umum guncangan variabel return Mudharabah direspon negatif oleh giro Wadiah. Tetapi seperti terlihat dari gambar, guncangan pada tingkat return Mudharabah tidak terlalu direspon oleh giro Wadiah. Respon giro Wadiah terhadap guncangan variabel return 
Mudharabah sudah terlihat stabil pada periode kedelapan peramalan. Mulai periode ini, respon permintaan giro Wadiah terhadap guncangan return Mudharabah sebesar satu standar deviasi hanya sekitar 0.4 persen.

Apabila dibandingkan bersebelahan (baca gambar IV.10) terlihat bahwa suku bunga memberikan pengaruh negatif terhadap permintaan giro konvensional lebih besar (0.014 SD) dari pada pengaruh return Mudharabah terhadap permintaan giro Wadiah (Islam) yang hampir tidak ada.

\section{b. Analisis Variance Decomposition untuk Giro}

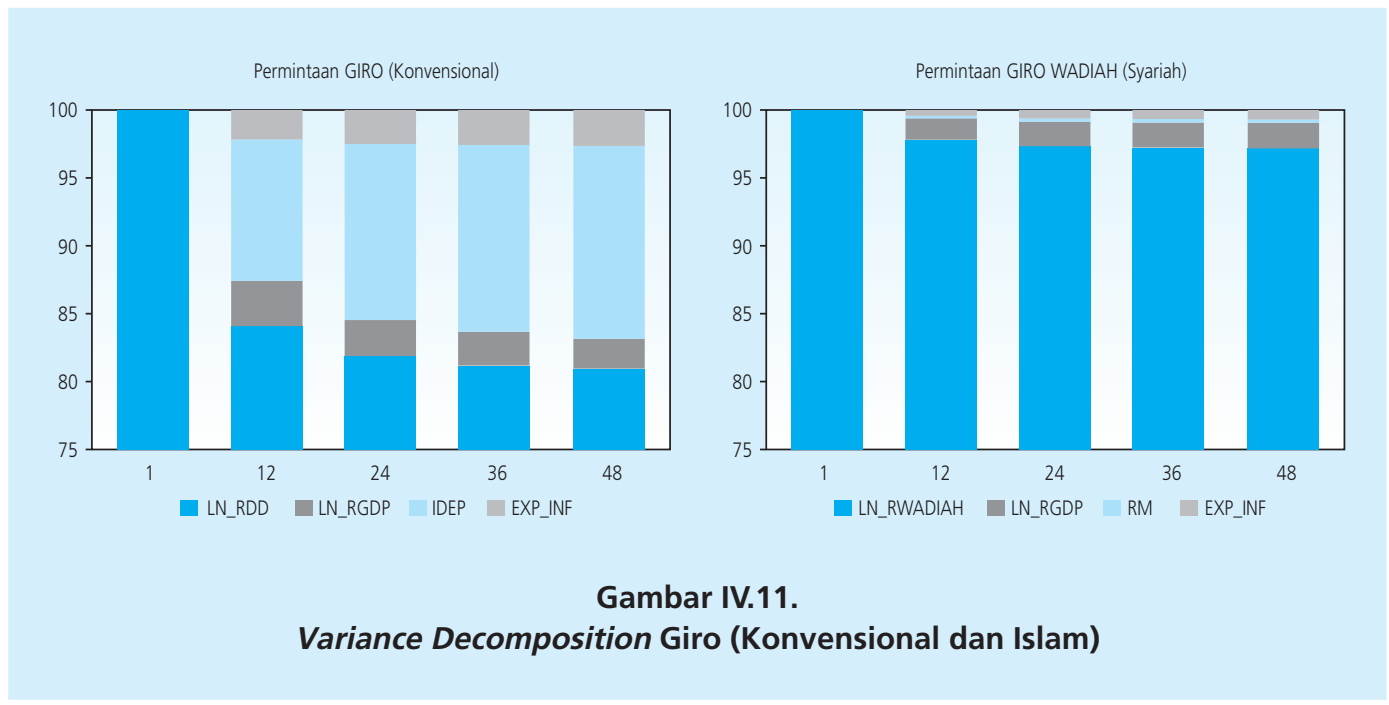

Pada periode pertama, fluktuasi variabel giro konvensional (baca gambar IV.11 kiri) dipengaruhi oleh guncangan giro konvensional itu sendiri sebesar 100 persen, sedangkan pengaruh variabel lain belum terlihat. Pada interval peramalan periode-periode selanjutnya, pengaruh guncangan giro konvensional itu sendiri makin menurun mempengaruhi fluktuasi giro konvensional tetapi masih dominan dengan kontribusi rata-rata sebesar 84 persen. Variabel suku bunga memberikan kontribusi terbesar kedua dalam menjelaskan variabilitas giro konvensional. Sementara guncangan variabel ekspektasi inflasi dan guncangan GDP tidak dominan mempengaruhi fluktuasi giro konvensional untuk setiap periode peramalan.

Sementara itu, fluktuasi variabel giro Wadiah (baca gambar IV.11 kanan) pada periode pertama, dipengaruhi oleh guncangan giroWadiah itu sendiri sebesar 100 persen, sedangkan pengaruh variabel lain belum terlihat. Pada interval peramalan periode-periode selanjutnya, pengaruh guncangan giro Wadiah itu sendiri makin menurun mempengaruhi fluktuasi giro 
Wadiah tetapi masih dominan dengan kontribusi rata-rata sebesar 97.7 persen. Sedangkan variabel-variabel lainnya tidak memberikan kontribusi yang besar dalam menjelaskan variabilitas giro Wadiah. Variabel tingkat return Mudharabah sendiri hanya mempunyai kontribusi ratarata sebesar 0.07 persen dalam menjelaskan fluktuasi giro Wadiah selama periode peramalan.

\section{IV.6 Tabungan Konvensional dan Tabungan Mudharabah}

\section{a. Analisis Impulse Response Function untuk Tabungan}

Rangkuman hasil analisis IRF untuk permintaan tabungan (konvensional dan Islam) dapat dibaca pada tabel IV.9 di bawah ini, serta gambar IV.16 dan gambar IV.17 di Lampiran.

\begin{tabular}{|c|c|c|}
\hline \multicolumn{3}{|c|}{$\begin{array}{l}\text { Tabel IV.9. } \\
\text { Respon Permintaan Saving Deposit }\end{array}$} \\
\hline & $\begin{array}{l}\text { Respon Saving Deposit } \\
\text { (Konvensional) }\end{array}$ & $\begin{array}{l}\text { Respon Tabungan } \\
\text { Mudharabah (Islam) }\end{array}$ \\
\hline $\begin{array}{l}\text { Guncangan PDB } \\
\text { Guncangan Ekspektasi Inflasi } \\
\text { Guncangan Suku Bunga } \\
\text { Guncangan Return Mudharabah }\end{array}$ & $\begin{array}{l}\text { Negatif dan permanen }-0.01 \text {, } \\
\text { stabil mulai periode ke- } 28 \\
\text { Negatif dan permanen }-0.004 \text {, } \\
\text { stabil mulai periode ke- } 30 \\
\text { Negatif dan permanen }-0.029 \text {, } \\
\text { stabil mulai periode ke- } 27 \\
\text { - }\end{array}$ & $\begin{array}{l}\text { Positif dan permanen } 0.006 \text {, } \\
\text { stabil mulai periode ke-15 } \\
\text { Negatif dan permanen }-0.041 \text {, } \\
\text { stabil mulai periode ke- } 17 \\
\text { - } \\
\text { Negatif dan permanen }-0.019 \text {, } \\
\text { stabil mulai periode ke- } 11\end{array}$ \\
\hline
\end{tabular}

Berdasarkan hasil analisis IRF tabungan konvensional (baca gambar IV.16 di Lampiran), dapat dilihat bahwa guncangan pada GDP, guncangan pada suku bunga, dan guncangan pada ekspektasi inflasi secara umum direspon negatif oleh tabungan. Guncangan pada GDP sebesar satu standar deviasi mulai direspon stabil oleh tabungan pada periode ke-28. Guncangan pada suku bunga sebesar satu standar deviasi mulai direspon stabil oleh tabungan pada periode ke-22 dengan respon sebesar 2.8 persen. Sedangkan respon yang stabil mulai ditunjukkan oleh tabungan terhadap guncangan variabel ekspektasi inflasi pada periode ke-26.

Untuk IRF tabungan Mudharabah (baca gambar IV.17 di Lampiran), dapat dilihat bahwa tabungan Mudharabah ini merespon positif terhadap guncangan variabel GDP, sedangkan guncangan pada return Mudharabah dan ekspektasi inflasi direspon negatif oleh tabungan Mudharabah. Respon positif tabungan Mudharabah terhadap guncangan variabel GDP sebesar satu standar deviasi mulai stabil pada periode ke-27. Sedangkan guncangan pada return Mudharabah dan ekspektasi inflasi sebesar satu standar deviasi direspon stabil mulai periode ke-11 dan periode ke-18. 
Response of LN_RSD to Cholesky

One S.D. IDËP Innovation

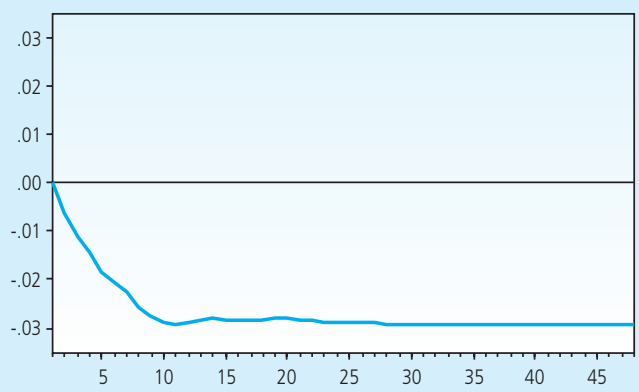

Response of LN_RSAV_MUDHARABAH to Cholesky

One S.D. RM Innovation

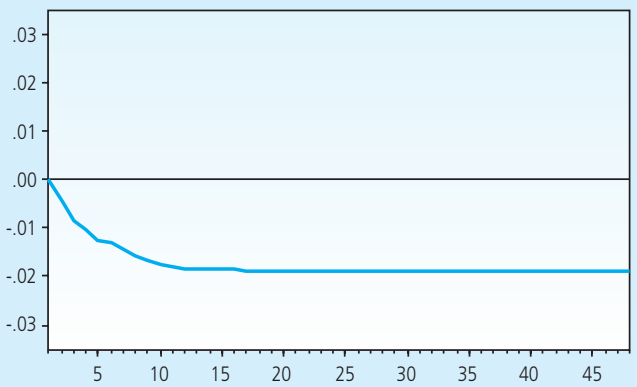

Gambar IV.12.

Respon Permintaan Tabungan terhadap Guncangan Return-nya (Konvensional terhadap Suku Bunga dan Islam terhadap Return Mudharabah)

Apabila dibandingkan bersebelahan (baca gambar IV.12) terlihat bahwa suku bunga memberikan pengaruh negatif terhadap permintaan tabungan konvensional lebih besar $(0.03$ SD) dari pada pengaruh negatif return Mudharabah terhadap permintaan tabungan Mudharabah (Islam) yang sebesar 0.02 SD.

\section{b. Analisis Variance Decomposition untuk Tabungan}
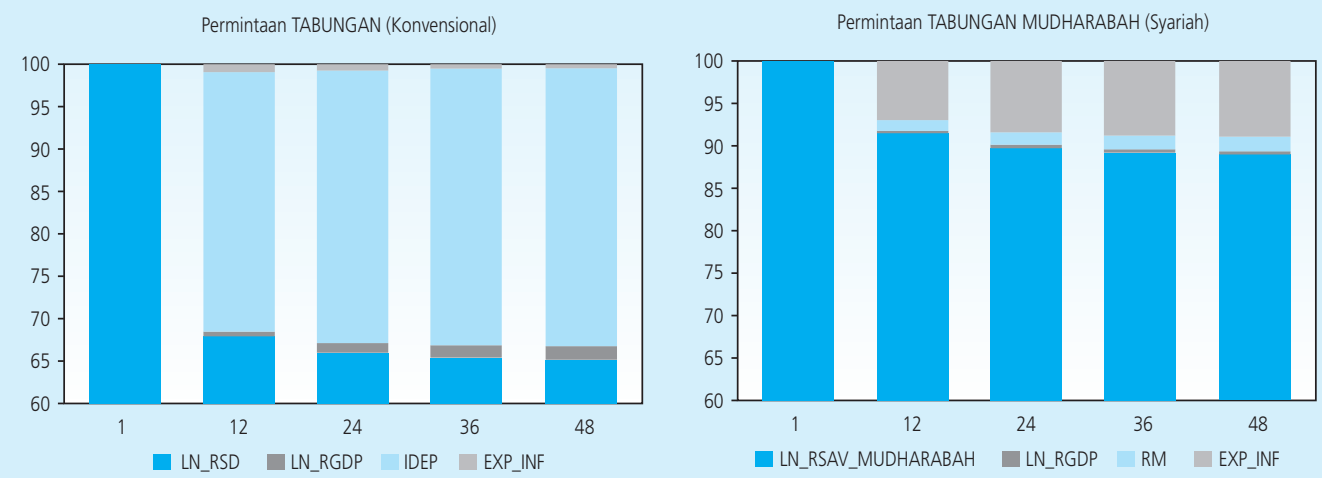

Gambar IV.13.

Variance Decomposition Tabungan (Konvensional dan Islam) 
Berdasarkan hasil variance decomposition, pada periode pertama variabilitas nilai tabungan konvensional dapat dijelaskan 100 persen oleh tabungan konvensional itu sendiri (baca gambar IV.13 kiri). Pada periode-periode berikutnya variabel tabungan konvensional masih menjadi variabel yang dominan dalam menjelaskan variabilitas nilai tabungan konvensional. Mulai dari periode ke-12 sampai periode ke-48, variabel kedua yang dominan dalam menjelaskan variabilitas dari nilai tabungan konvensional adalah variabel suku bunga. Pengaruh rata-ratanya adalah sebesar 31.7 persen. Sedangkan variabel GDP dan ekspektasi inflasi tidak dominan dalam menjelaskan fluktuasi nilai tabungan konvensional.

Pada variance decomposition tabungan Mudharabah (baca gambar IV.13 kanan), variabel tabungan Mudharabah itu sendiri dominan dalam menjelaskan variabilitas nilai tabungan Mudharabah dengan kontribusi rata-rata sebesar 91 persen. Sedangkan variabel lain yang dominan kedua dalam menjelaskan fluktuasi nilai tabungan Mudharabah adalah variabel ekspektasi inflasi. Seperti yang telah dijelaskan sebelumnya, hal ini bisa terjadi mengingat sistem perbankan syariah dalam dual financial system masih menggunakan ung fiat konvensional yang masih bersifat inflatoir. Sehingga pengaruh ekspektasi inflasi masih terlihat pada tabungan Mudharabah. Kontribusi rata-ratanya dari periode ke-12 sampai periode ke-48 adalah sebesar 8.37 persen. Sedangkan variabel GDP dan tingkat return Mudharabah tidak dominan dalam menjelasakan variabilitas nilai tabungan Mudharabah.

\section{IV.7 Deposito Konvensional dan Deposito (Investasi) Mudharabah}

\section{a. Analisis Impulse Response Function untuk Deposito}

Rangkuman hasil analisis IRF untuk permintaan deposito (konvensional dan Islam) dapat dibaca pada tabel IV.10 di bawah ini, serta gambar IV.20 dan gambar IV.21 di Lampiran.

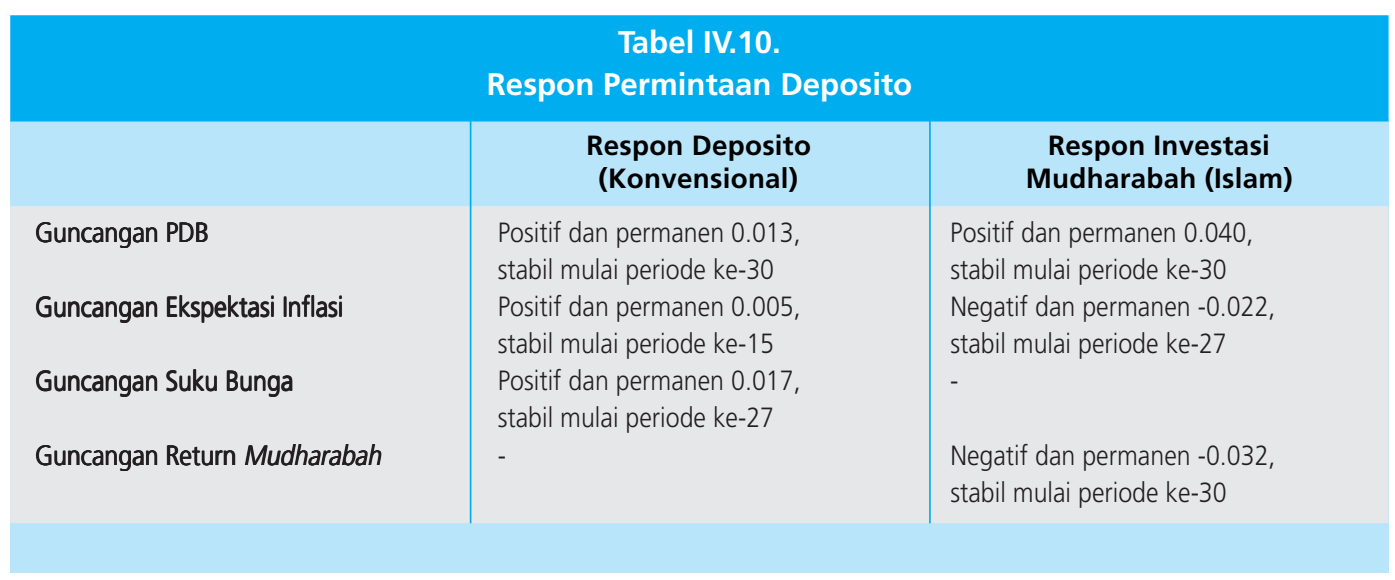


Berdasarkan hasil analisis IRF untuk permintaan deposito konvensional (baca gambar IV.20 di Lampiran), dapat dilihat bahwa guncangan pada GDP, ekspektasi inflasi, dan suku bunga direspon positif oleh deposito. Guncangan pada GDP sebesar satu standar deviasi mulai direspon stabil oleh deposito pada periode ke-23 sebesar 1.4 persen. Guncangan pada suku bunga sebesar satu standar deviasi mulai direspon stabil pada periode ke-27 sebesar 1.5 persen. Sedangkan guncangan pada variabel ekspektasi inflasi sebesar satu standar deviasi mulai direspon stabil pada periode ke-14 sebesar 0.5 persen.

Sementara itu, secara umum dapat dilihat bahwa deposito Mudharabah merespon positif terhadap guncangan GDP, dan merespon negatif terhadap guncangan return Mudharabah dan ekspektasi inflasi (baca gambar IV.21 di Lampiran). Guncangan pada GDP sebesar satu standar deviasi mulai direspon stabil oleh deposito Mudharabah pada periode ke-32 sebesar 4 persen. Guncangan pada tingkat return Mudharabah sebesar satu standar deviasi mulai direspon stabil pada periode ke-24 sebesar 3 persen. Sedangkan guncangan pada variabel ekspektasi inflasi sebesar satu standar deviasi mulai direspon stabil pada periode ke-24 sebesar 2 persen.
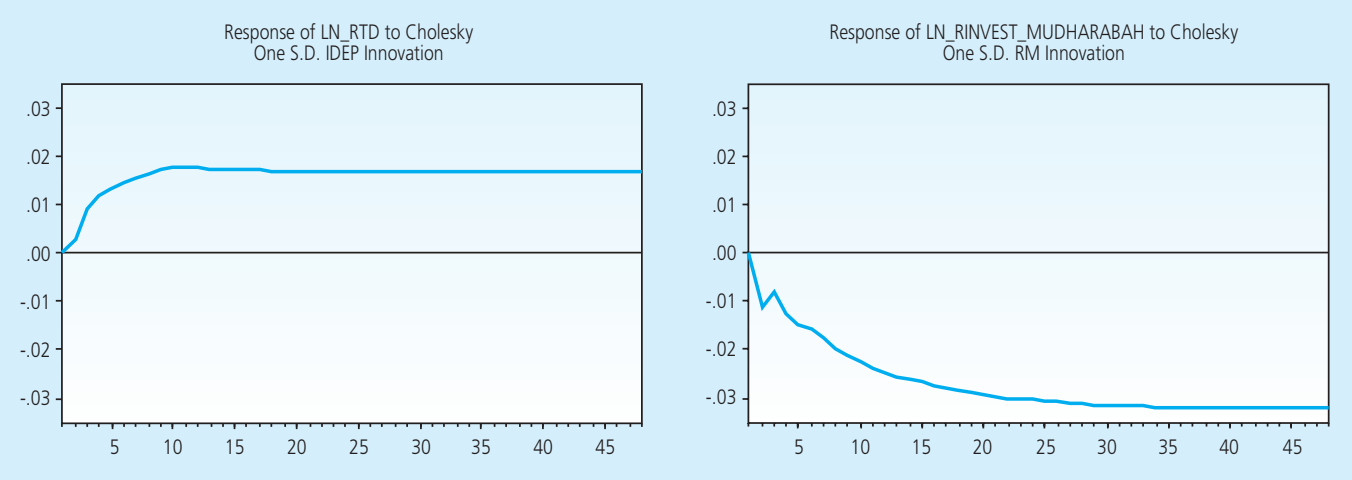

Gambar IV.14.

Respon Permintaan Deposito terhadap Guncangan Return-nya (Konvensional terhadap Suku Bunga dan Islam terhadap Return Mudharabah)

Apabila dibandingkan bersebelahan (baca gambar IV.14) terlihat bahwa suku bunga memberikan pengaruh positif terhadap permintaan deposito konvensional, sedangkan return Mudharabah memberikan pengaruh negatif terhadap permintaan deposito Mudharabah (Islam). 


\section{b. Analisis Variance Decomposition untuk Deposito}

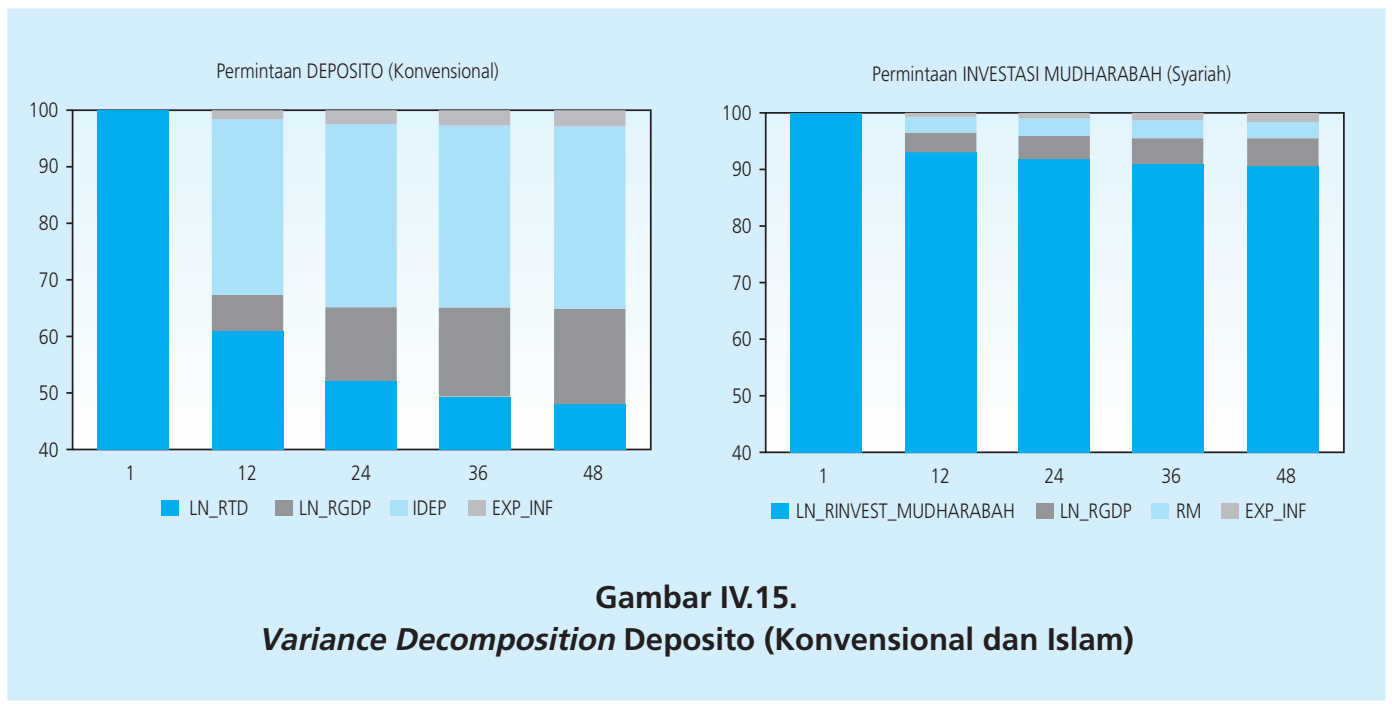

Hasil analisis variance decomposition untuk deposito konvensional (baca gambar IV.15 kiri) menunjukkan bahwa pada periode pertama variabilitas nilai deposito dapat dijelaskan oleh deposito itu sendiri sebesar 100 persen. Pada periode ke-12 sampai periode ke-48, kontribusi rata-rata deposito dalam menjelaskan fluktuasi nilai deposito itu sendiri hanya sebesar 51.4 persen. Pada periode ke-12 sampai ke-48, variabel yang dominan kedua dalm menjelaskan variabilitas nilai deposito adalah variabel suku bunga. Kontribusi rata-ratanya sendiri sebesar 29.3 dalam menjelaskan fluktuasi deposito. Variabel GDP merupakan variabel dominan ketiga dalam menjelaskan variabilitas nilai deposito, sedangkan variabel ekspektasi inflasi tidak dominan dalam menjelaskan nilai deposito.

Hasil analisis variance decomposition untuk deposito Mudharabah (baca gambar IV.15 kanan) menunjukkan bahwa pada periode pertama variabilitas nilai deposito Mudharabah dapat dijelaskan deposito Mudharabah itu sendiri sebesar 100 persen. Pada periode ke-12 sampai periode ke-48, kontribusi rata-rata deposito Mudharabah dalam menjelaskan fluktuasi nilai deposito Mudharabah itu sendiri sebesar 92.3 persen. Pada periode ke-12 sampai ke-48, variabelvariabel lainnya kurang dapat memberikan kontribusi dalam menjelaskan fluktuasi nilai deposito Mudharabah. 


\section{KESIMPULAN DAN REKOMENDASI}

\section{V.1 Kesimpulan}

- Pada Negara yang menerapkan sistem keuangan/perbankan ganda (konvensional dan Islam), otoritas moneter mempunyai tanggung jawab untuk menjaga stabilitas moneter dan sistem keuangan, serta mensinergikan ke dua sistem untuk mengoptimalkan keuntungan bagi kesejahteraan masyarakat. Sinergi ke dua sistem ini harus menjaga esensi dan karakteristik masing-masing, dan tidak meleburkan salah satu system ke system yang lain, untuk mencapai harmonisasi yang berkessinambungan yang memastikan stabilitas system keuangan, mempercepat aktivitas ekonomi di sector riil, dan meningkatkan kesejahteraan yang merata.

- Tiga pilar utama yang membedakan sistem moneter konvensional dan sistem moneter Islam adalah sistem uang fiat vs. sistem uang Islam, fractional reserve banking system vs. 100 percent reserve banking system, dan sistem bunga vs. sistem bagi hasil. Pada sistem moneter ganda kontemporer, hanya sistem bunga vs. sistem bagi hasil yang membedakan ke dua sistem moneter tersebut.

- Hasil pengujian menunjukkan bahwa return bagi hasil (Mudharabah) berpengaruh negatif terhadap permintaan semua komponen uang Islam (uang kartal, giro Wadiah, tabungan Mudharabah, dan deposito Mudharabah). Hasil pengujian juga menunjukkan bahwa permintaan uang Islam lebih cepat stabil dari pada permintaan uang konvensional dalam merespon guncangan dari variabel-variabel lain.

- Dalam permintaan uang konvensional, suku bunga mempunyai pengaruh yang besar pada perilaku permintaan uang kartal (20\%-29\%), sedangkan dalam permintaan uang Islam, return Mudharabah hampir tidak mempunyai pengaruh pada perilaku permintaan uang Islam.

- Permintaan uang konvensional secara umum menunjukkan perilaku motif untuk transaksi dan berjaga-jaga (uang kartal, giro, dan tabungan), serta perilaku motif untuk spekulasi/ investasi (deposito). Sedangkan, permintaan uang Islam secara umum hanya menunjukkan perilaku motif untuk transaksi dan berjaga-jaga saja.

- Temuan lainnya adalah bahwa ternyata tabungan di Indonesia memiliki karakteristik seperti giro yang digunakan untuk keperluan transaksi, sehingga tabungan seharusnya dimasukkan dalam definisi M1 dan dikeluarkan dari definisi M2.

\section{V.2 Rekomendasi}

- Otoritas moneter harus secara bertahap mengubah mindset 'cara pandang' mereka dari operasi moneter konvensional ke operasi moneter ganda, dan mulai memikirkan kemungkinan penggunaan return Syariah sebagai acuan policy rate 'kebijakan tingkat 
pengembalian' untuk dapat mencapai tujuan utama dalam memaksimalkan kesejahteraan masyarakat yang merata dan keadilan, serta meminimalkan inefisiensi.

- Perlu dilakukannya kajian-kajian lanjutan tentang sinergi sistem moneter ganda dan bagaimana memaksimalkan kelebihan system ketika diimplementasikan, serta pengembangan operasional instrumen kebijakan moneter ganda yang sesuai dan dapat mengoptimalkan kelebihan system moneter ganda.

- Selain itu, perlu juga dilakukan kajian-kajian mendalam tentang system uang fiat vs. system uang Islam dan fractional reserve banking system vs. 100 percent reserve banking system, untuk membuktikan bahwa system keuangan Islam yang comprehensive bekerja lebih baik dari pada system keuangan Islam kontemporer dalam mencapai kesejahteraan masyarakat yang merata dan keadilan. 


\section{Daftar Pustaka}

Achsani, N.A., Oliver H., dan Hizir S. (2005), "Econometric and Fuzzy Modelling of Indonesian Money Demand", dalam: Cizek, Pavel, Wolfgang H., and Rafal W. Statistical Tools For Finance and Insurance, Springer-Verlag Berlin Heidelberg, Germany.

Ascarya (2007), "Optimum Monetary Policy under Dual Financial/Banking System", Paper, Universiti Sains Islam Malaysia (USIM) Islamic Economics Conference (IECONS 2007), Kuala Lumpur, Malaysia, 17-19 Juli.

Astiyah, S. dan D.F. Anugrah (2006), "Kebijakan Moneter Tepadu dalam Dual Banking System," Working Paper, Jakarta, Indonesia: Biro Riset Ekonomi, Direktorat Riset Ekonomi dan Kebijakan Moneter, Bank Indonesia.

Chapra, M.U. (1996), "Monetary Management in Islamic Economy," Islamic Economic Studies, Vol.4, No.1.

Darrat, A.F. (2000), "On The Efficiency of Interest-free Monetary System: A Case Study", Paper, ERF's Seven $^{\text {th }}$ Annual Conference, Amman-Jordan, 26-29 Oktober.

Fardmanesh, M. dan S.A. Siddiqui (1994), "Financial Instability and a Share Economy," Eastern Economic Journal, USA, Winter 1994, pp. 75-84.

Hasanah, Heni, Ascarya dan N.A. Achsani (2008), "Perilaku Agregat Moneter dalam Sistem

Keuangan/Perbankan Ganda di Indonesia," Jurnal Ekonomi dan Bisnis Indonesia, Vol.23,

No. 1 Januari 2008. Forthcoming

Izhar, H. dan Asutay, M. (2007), "The Controllability and Reliability of Monetary Policy in Dual

Banking System: Evidence from Indonesia", Paper, International Islamic University Malaysia (IIUM) International Conference on Islamic Banking and Finance (IICiBF), Kuala Lumpur, Malaysia, 23-25 April.

Kaleem, A. (2000), "Modeling Monetary Stability under Dual Banking System: The Case of Malaysia". International Journal of Islamic Financial Services, Vol. 2, No. 1.

Khan, M. (1986), "Islamic Interest Free Banking," IMF Staff Papers, Vol.33, No. 1, pp. 1-27.

Kia, A. (2001), "Interest-free and Interest-bearing Money Demand: Policy Invariance and Stability", Paper, Department of Economics, Emory University, Atlanta.

Mankiw, N.G. (2003), Teori Makroekonomi, terjemahan, Erlangga, Jakarta.

Meera, A.K.M. (2004), The Theft of Nations: Returning to Gold, Selangor, Malaysia: Pelanduk Publications. 
Mishkin, F.S. (2001), The Economics of Money, Banking, and Financial Markets, Colombia University.

Ryandono, M.N.H. (2006), "Mempertanyakan Kebenaran Paradigma Hubungan Bunga, Investasi (Kredit), dan Pertumbuhan Ekonomi: Haramnya Sistem Bunga (Riba) Secara Teoritik dan Empirik." Paper. Dipresentasikan pada Seminar dan Kolokium Nasional, ITB. Bandung, Indonesia: SBM-ITB, September.

Sakti, A. (2007), Sistem Ekonomi Islam: Jawaban atas Kekacauan Ekonomi Modern, Paradigma \& Aqsa Publishing, Jakarta.

Zangeneh, H. (1995), "A Macroeconomic Model of an Interest-free System," The Pakistan Development Review, Vol.34, No.1, pp. 55-68. 


\section{LAMPIRAN}

\begin{tabular}{|c|c|c|c|c|}
\hline \multirow{2}{*}{ Variabel } & \multicolumn{2}{|c|}{ Nilai ADF } & \multicolumn{2}{|c|}{ Nilai Kritis McKinnon 5 \% } \\
\hline & Level & 1st Difference & Level & 1st Difference \\
\hline LN_RCURRENCY & -3.192561 & -4.686571 & -3.476275 & -1.945669 \\
\hline LN_RDD & -2.841324 & -4.862425 & -3.476275 & -1.945669 \\
\hline LN_RSD & -1.431788 & -3.163332 & -3.476275 & -1.945669 \\
\hline LN_RTD & -0.630974 & -4.434394 & -3.476275 & -1.945669 \\
\hline LN_RWADIAH & -2.583077 & -5.247550 & -3.476275 & -1.945669 \\
\hline LN_RSAV_MUDHARABAH & -1.931544 & -3.265039 & -3.476275 & -1.945669 \\
\hline LN_RINVEST_MUDHARABAH & -0.652513 & -2.832839 & -3.476275 & -1.945669 \\
\hline LN_RGDP & -1.291937 & -2.568569 & -3.476275 & -1.945669 \\
\hline EXP_INF & -4.353697 & -7.525936 & -3.476275 & -1.945669 \\
\hline IDEP & -2.617818 & -2.376054 & -3.476275 & -1.945669 \\
\hline RM & -1.821981 & -6.917242 & -3.476275 & -1.945669 \\
\hline
\end{tabular}

\begin{tabular}{|c|c|c|c|c|}
\hline \multicolumn{5}{|c|}{$\begin{array}{l}\text { Tabel Lampiran IV.2. } \\
\text { Hasil Pengujian Lag Optimal (Model Konvensional) }\end{array}$} \\
\hline Lag & LN_RCURRENCY & LN_RDD & LN_RSD & LN_RTD \\
\hline 0 & -4.353199 & -5.093219 & -6.088690 & -6.172428 \\
\hline 1 & -6.512108 & -7.091669 & -8.212920 & -8.146018 \\
\hline 2 & -7.512774 & -7.771428 & -9.098839 & -9.044000 \\
\hline 3 & $-7.567549 *$ & -7.916464 * & $-9.367432^{*}$ & $-9.106017^{*}$ \\
\hline 4 & -6.899432 & -7.492724 & -9.133450 & -8.421906 \\
\hline 5 & -6.742715 & -7.496237 & -8.989849 & -8.595646 \\
\hline
\end{tabular}

\begin{tabular}{|c|c|c|c|c|}
\hline Lag & LN_RCURRENCY & LN_RWADIAH & $\begin{array}{c}\text { LN_RSAV_MU } \\
\text { DHARABAH }\end{array}$ & $\begin{array}{c}\text { LN_RINVEST_MU } \\
\text { DHARABAH }\end{array}$ \\
\hline 0 & -1.613846 & 0.066684 & -0.871877 & -1.603561 \\
\hline 1 & -2.418921 & -0.354656 & -1.325949 & -2.100949 \\
\hline 2 & $-3.400025^{\star}$ & $-1.026714^{*}$ & $-2.118458^{*}$ & $-2.892165^{*}$ \\
\hline 3 & -3.161683 & -0.826588 & -1.893530 & -2.686452 \\
\hline 4 & -2.571215 & -0.163521 & -1.281218 & -2.022378 \\
\hline 5 & -2.470653 & -0.122472 & -1.166358 & -2.044016 \\
\hline
\end{tabular}




\begin{tabular}{|c|c|c|c|c|c|}
\hline \multicolumn{6}{|c|}{$\begin{array}{c}\text { Tabel Lampiran IV.4. } \\
\text { Hasil Pengujian Kointegrasi (Konvensional) }\end{array}$} \\
\hline \multirow{3}{*}{ Model } & \multirow[b]{2}{*}{$\mathrm{HO}$} & \multicolumn{4}{|c|}{ Trace Statistics } \\
\hline & & $r=0$ & $r<=1$ & $r<=2$ & $r<=3$ \\
\hline & $\mathrm{H} 1$ & $r>=1$ & $r>=2$ & $r>=3$ & $r>=4$ \\
\hline LN_RCURRENCY & & 53.41750 & 21.14002 & 10.54684 & 3.623332 \\
\hline LN_RDD & & 56.81861 & 21.99543 & 9.736220 & 2.859469 \\
\hline LM1ISLR & & 62.70716 & 21.54275 & 8.663544 & 2.158515 \\
\hline LM2ISLR & & 55.49325 & 24.28946 & 8.422019 & 2.341894 \\
\hline $5 \%$ critical value & & 39.89 & 24.31 & 12.53 & 3.84 \\
\hline
\end{tabular}

\begin{tabular}{|c|c|c|c|c|c|}
\hline \multicolumn{6}{|c|}{$\begin{array}{l}\text { Tabel Lampiran IV.5. } \\
\text { Hasil Pengujian Kointegrasi (Islam) }\end{array}$} \\
\hline \multirow{3}{*}{ Model } & & \multicolumn{4}{|c|}{ Trace Statistics } \\
\hline & HO & $r=0$ & $r<=1$ & $r<=2$ & $r<=3$ \\
\hline & $\mathrm{H1}$ & $r>=1$ & $r>=2$ & $r>=3$ & $r>=4$ \\
\hline LN_RCURRENCY & & 59.65586 & 22.32436 & 7.336443 & 1.724978 \\
\hline LN_RWADIAH & & 50.87617 & 18.41788 & 4.714071 & 1.315290 \\
\hline LN_RSAV_MUDHARABAH & & 50.56683 & 19.51537 & 7.886067 & 3.600525 \\
\hline LN_RINVES T_MUDHARABAH & & 63.37379 & 25.11901 & 12.63209 & 3.669596 \\
\hline $5 \%$ critical value & & 39.89 & 24.31 & 12.53 & 3.84 \\
\hline
\end{tabular}


Response to Cholesky One S.D. Innovations

Response of LN_RCURRENCY to LN_RCURRENCY

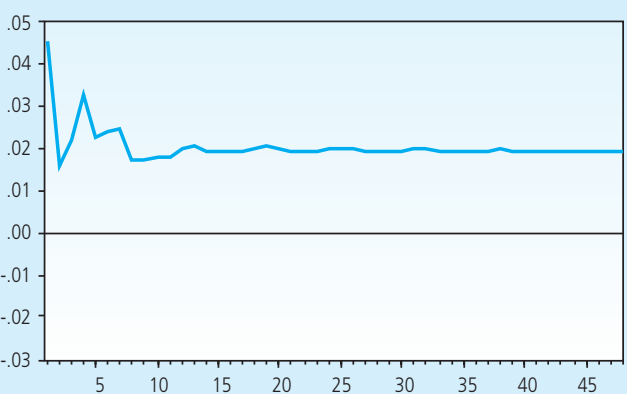

Response of LN_RCURRENCY to IDEP

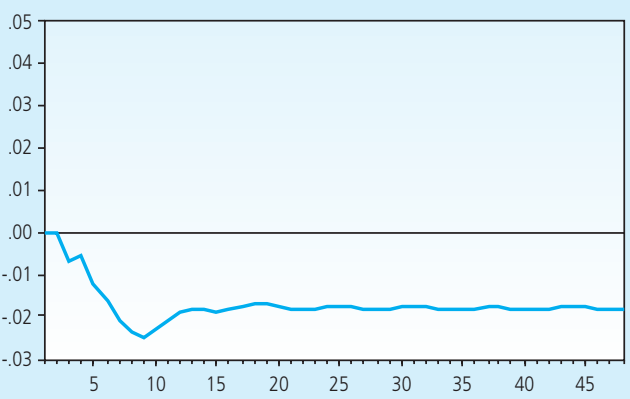

Response of LN_RCURRENCY to LN_RGDP

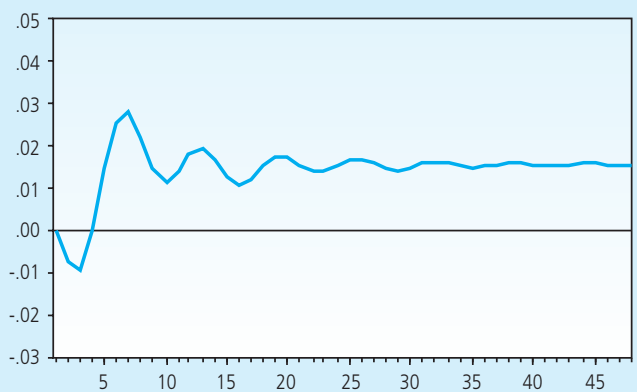

Response of LN_RCURRENCY to EXP_INF

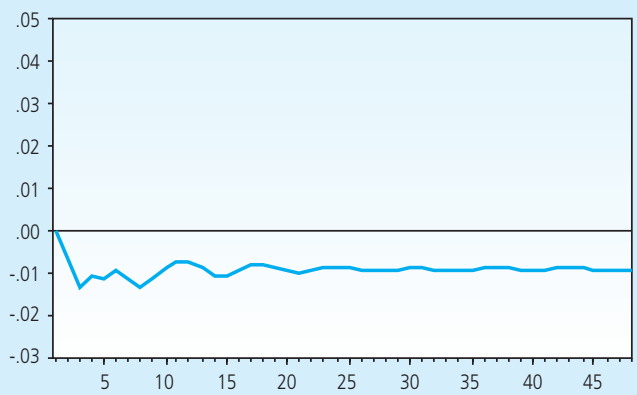

Gambar Lampiran IV.8.

Respon Permintaan Uang Kartal terhadap Guncangan Variabel PDB, Ekspektasi Inflasi, dan Suku Bunga Sebesar Satu Standar Deviasi

Response to Cholesky One S.D. Innovations

Response of LN_RCURRENCY to LN_RCURRENCY

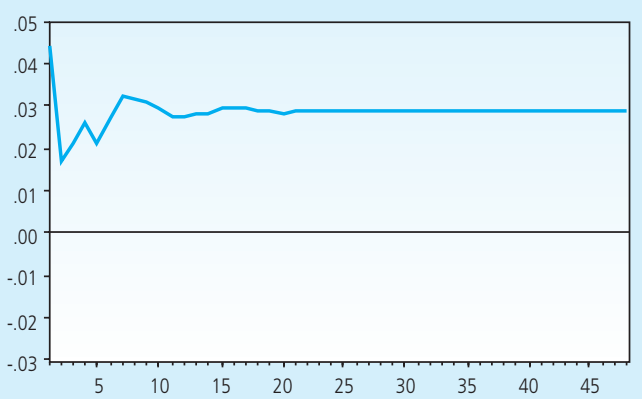

Response of LN_RCURRENCY to LN_RGDP

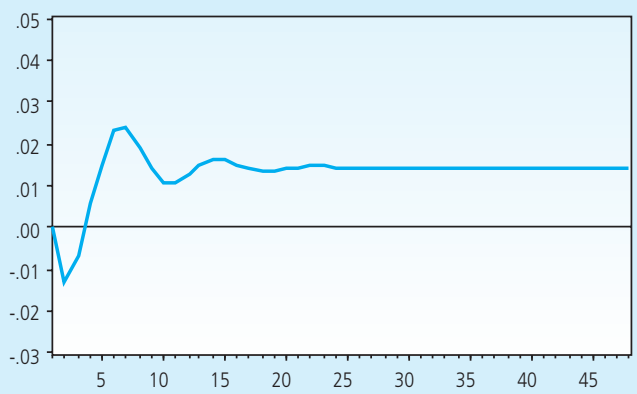

Gambar Lampiran IV.9.

Respon Permintaan Uang Kartal terhadap Guncangan Variabel PDB, Ekspektasi Inflasi, dan Return Mudharabah Sebesar Satu Standar Deviasi 
Response of LN RCURRENCY to RM

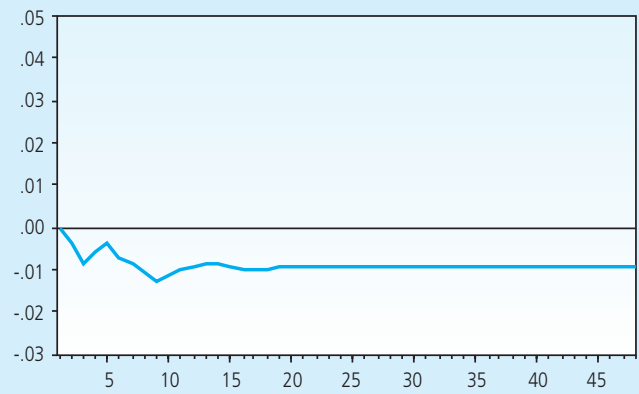

Response of LN RCURRENCY to EXP INF

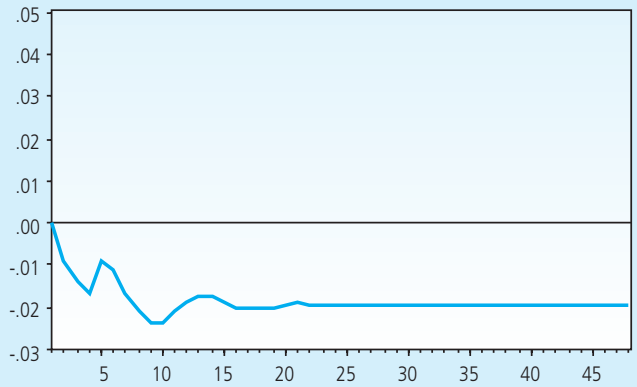

Gambar Lampiran IV.9. (lanjutan)

Respon Permintaan Uang Kartal terhadap Guncangan Variabel PDB, Ekspektasi Inflasi, dan Return Mudharabah Sebesar Satu Standar Deviasi

Response to Cholesky One S.D. Innovations

Response of LN_RDD to LN_RDD

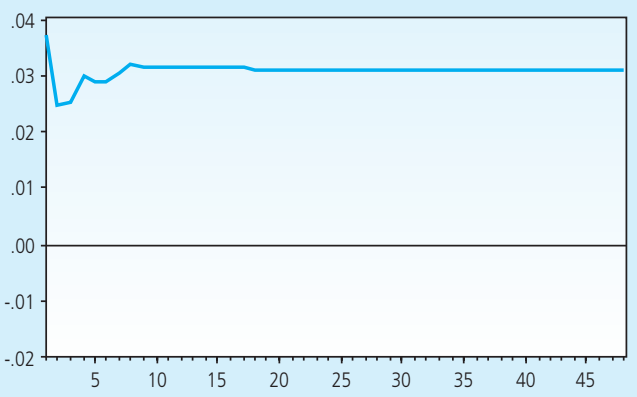

Response of LN_RDD to IDEP

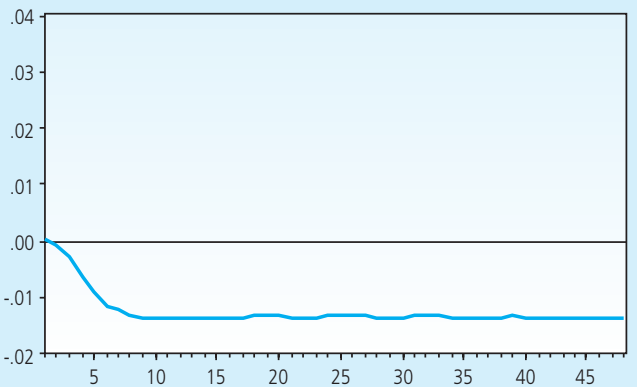

Response of LN_RDD to LN_RGDP

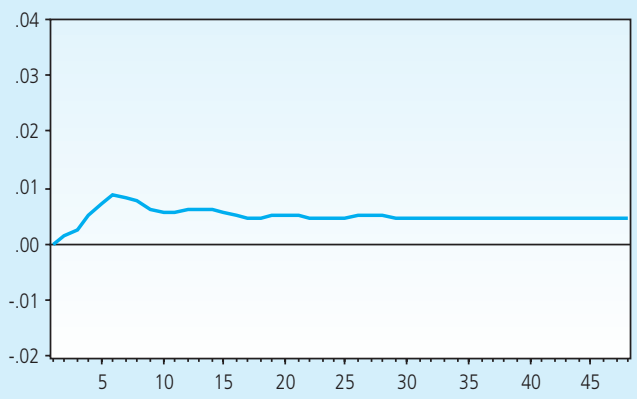

Response of LN_RDD to EXP_INF

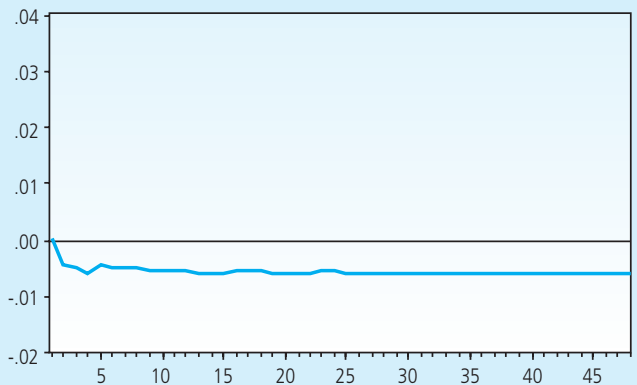

Gambar Lampiran IV.12.

Respon Permintaan Giro Konvensional terhadap Guncangan Variabel GDP, Expektasi Inflasi, dan Suku Bunga Sebesar Satu Standar Deviasi 
Response to Cholesky One S.D. Innovations

Response of LN_RWADIAH to LN_RWADIAH

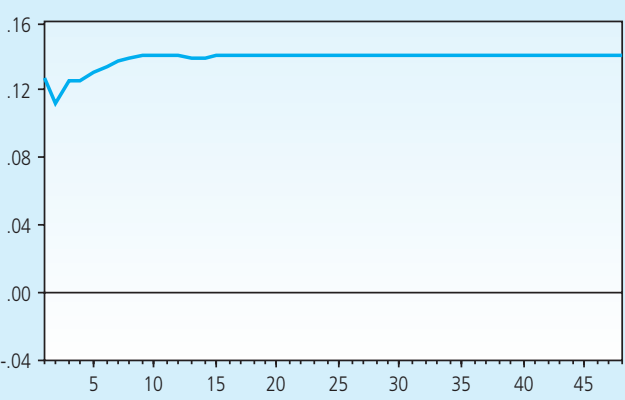

Response of LN_RWADIAH to RM

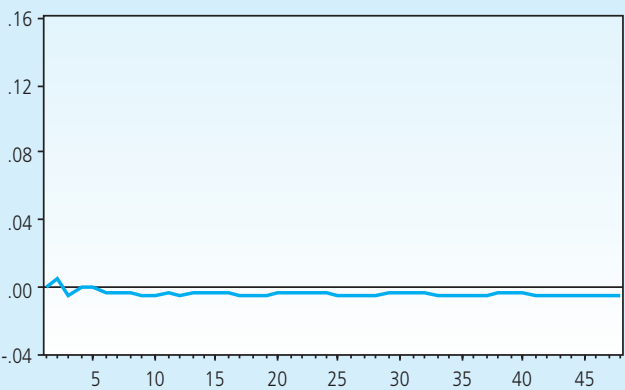

Response of LN_RWADIAH to LN_RGDP

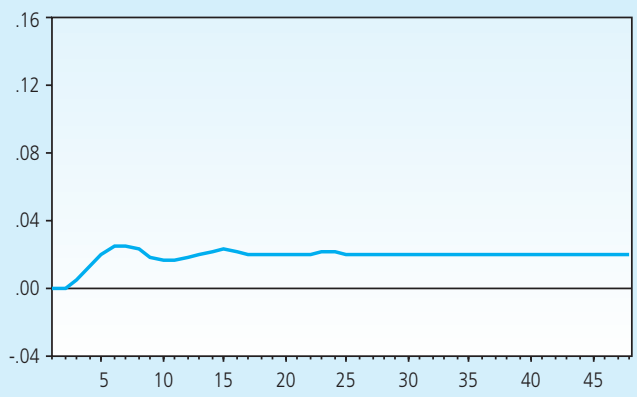

Response of LN_RWADIAH to EXP_INF

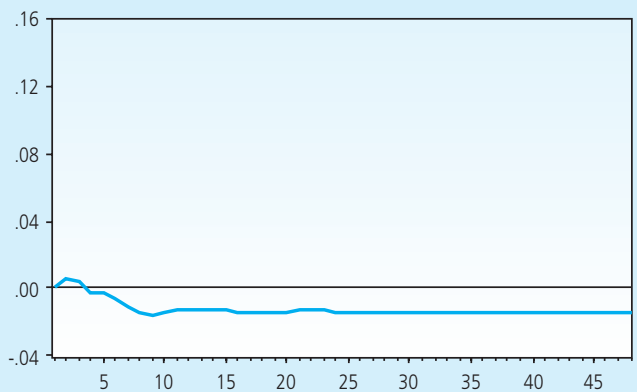

Gambar Lampiran IV.13.

Respon Permintaan Giro Wadiah terhadap Guncangan Variabel GDP, Ekspektasi Inflasi, dan Return Mudharabah Sebesar Satu Standar Deviasi

Response to Cholesky One S.D. Innovations

Response of LN_RSD to LN_RSD

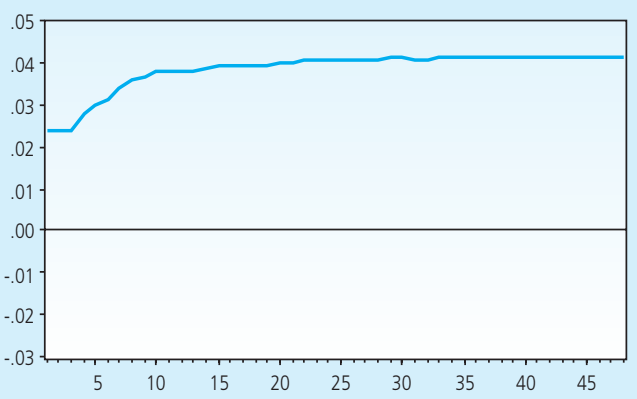

Response of LN_RSD to IDEP

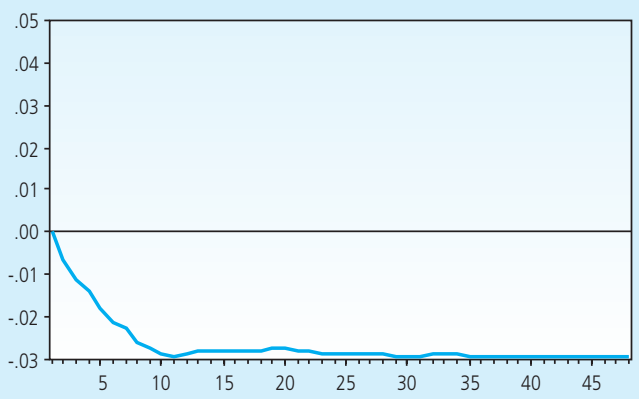

Gambar Lampiran IV.16.

Respon Saving Deposit terhadap Guncangan Variabel GDP, Expected Inflation, dan Suku Bunga Sebesar Satu Standar Deviasi 
Response of LN_RSD to LN_RGDP

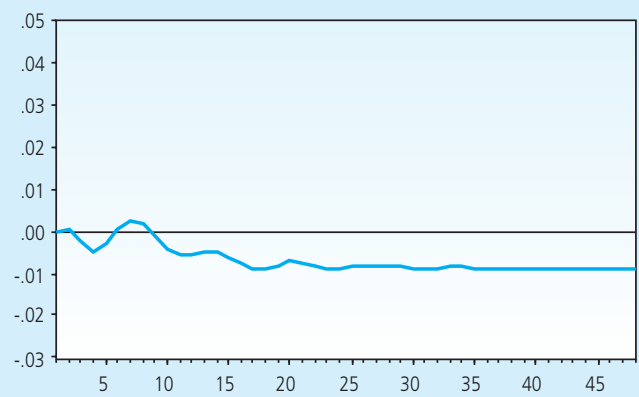

Response of LN RSD to EXP INF

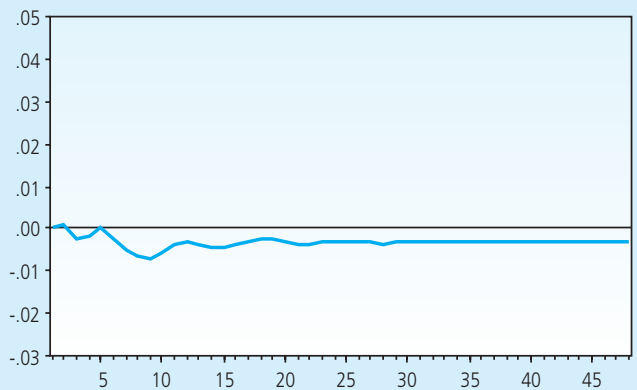

Gambar Lampiran IV.16. (lanjutan)

Respon Saving Deposit terhadap Guncangan Variabel GDP,

Expected Inflation, dan Suku Bunga Sebesar Satu Standar Deviasi

Response to Cholesky One S.D. Innovations

Response of LN_RSAV_MUDHARABAH to LN_RSAV_MUDHARABAH

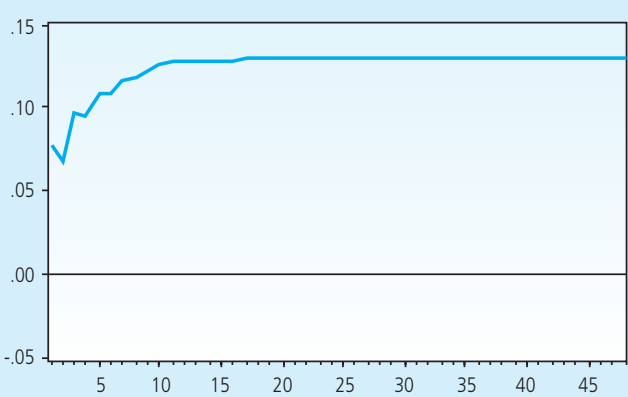

Response of LN_RSAV_MUDHARABAH to RM

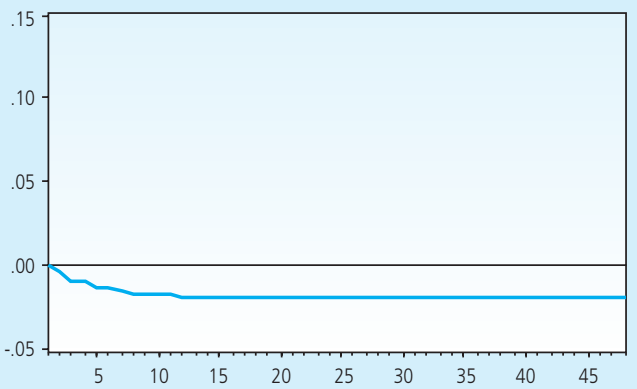

Response of LN_RSAV_MUDHARABAH to LN_RGDP

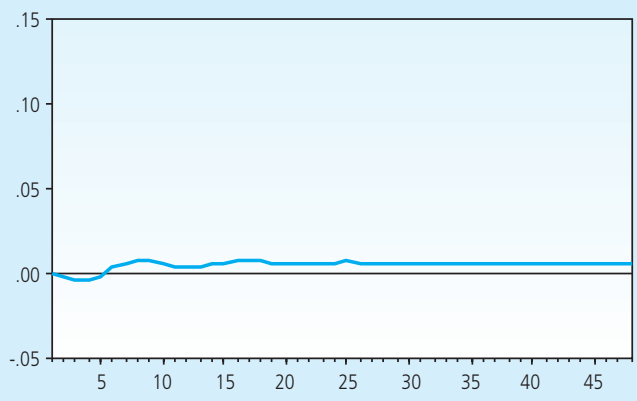

Response of LN_RSAV_MUDHARABAH to EXP_INF

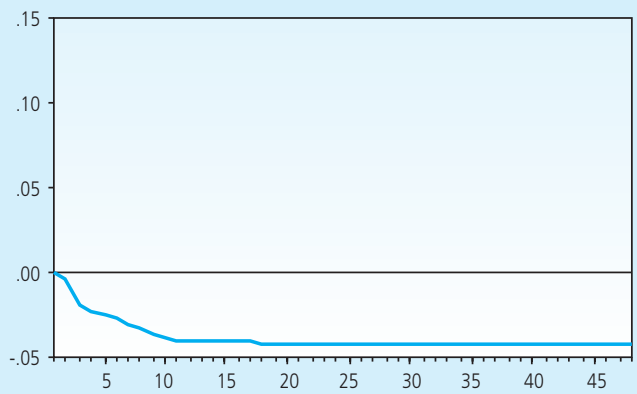

Gambar Lampiran IV. 17.

Respon Tabungan Mudharabah terhadap Guncangan Variabel GDP, Expected Inflation, dan Return Mudharabah Sebesar Satu Standar Deviasi 
Response to Cholesky One S.D. Innovations

Response of LN_RTD to LN_RTD

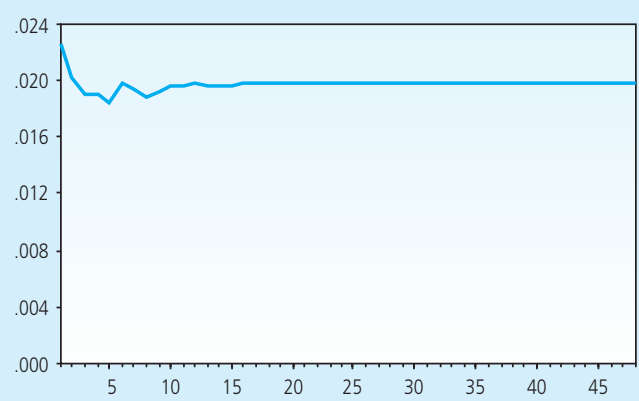

Response of LN_RTD to LN_RGDP

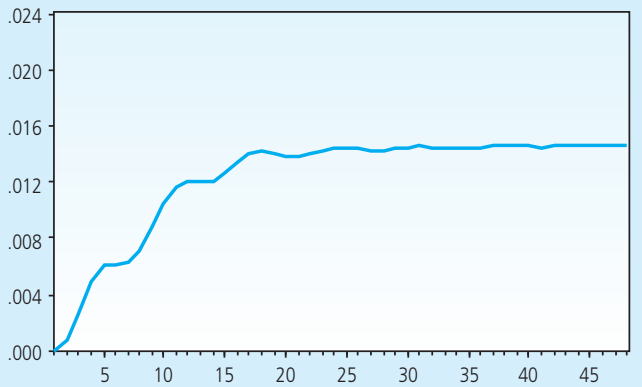

Response of LN_RTD to IDEP

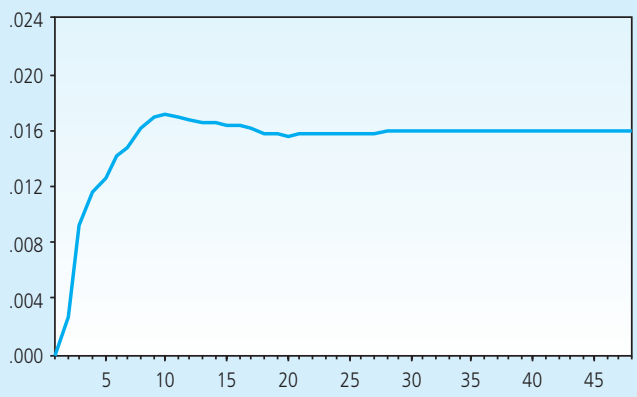

Response of LN_RTD to EXP_INF

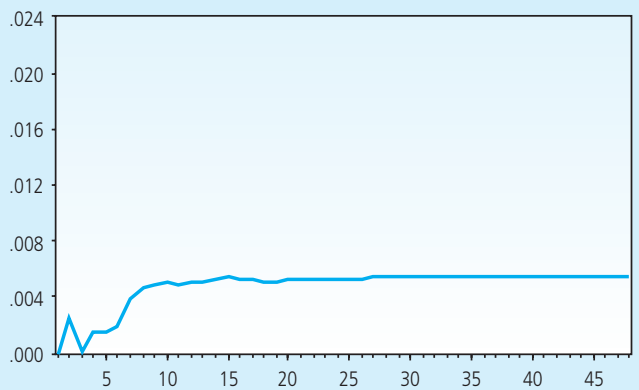

Gambar Lampiran IV.20.

Respon Deposito Konvensional terhadap Guncangan Variabel GDP, Expected Inflation, dan Suku Bunga Sebesar Satu Standar Deviasi

Response to Cholesky One S.D. Innovations

Response of LN_RINVEST_MUDHARABAH to LN_RINVEST_MUDHARABAH

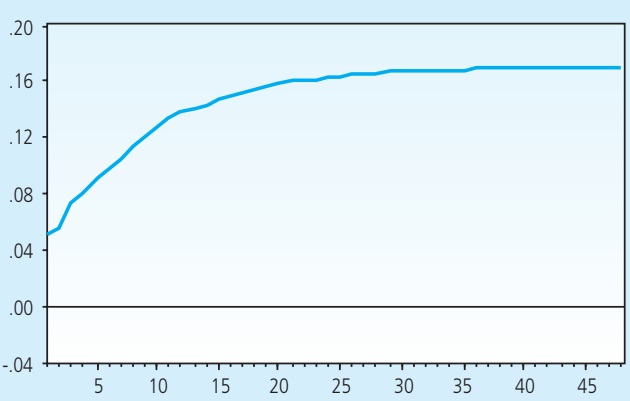

Response of LN_RINVEST_MUDHARABAH to LN_RGDP

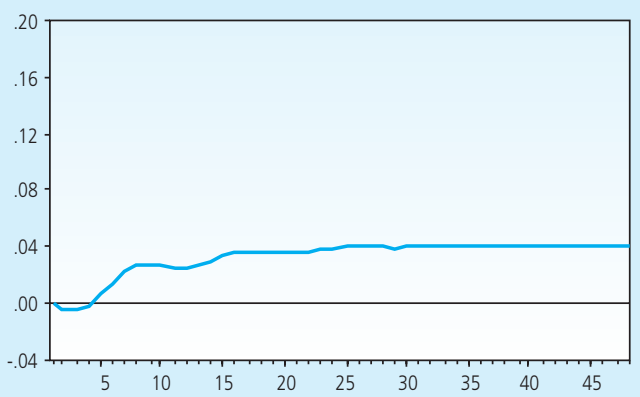

Gambar Lampiran IV.21.

Respon Deposito Mudharabah terhadap Guncangan Variabel GDP, Ekspektasi Inflasi, dan Return Mudharabah Sebesar Satu Standar Deviasi 
Response of LN_RINVEST_MUDHARABAH to RM

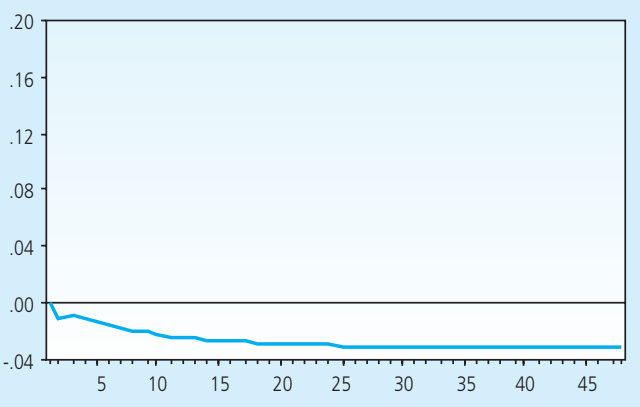

Response of LN_RINVEST_MUDHARABAH to EXP_INF

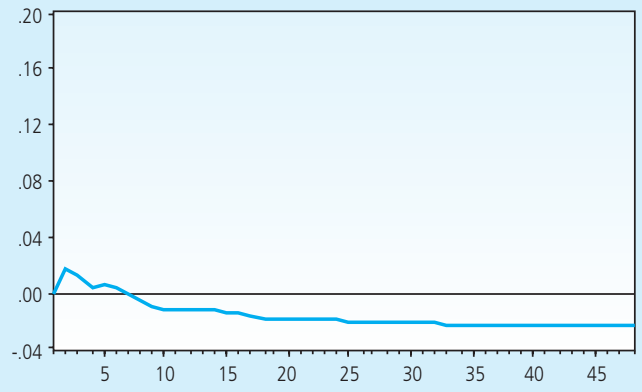

Gambar Lampiran IV.21. (lanjutan)

Respon Deposito Mudharabah terhadap Guncangan Variabel GDP,

Ekspektasi Inflasi, dan Return Mudharabah Sebesar Satu Standar Deviasi 